\title{
Corporate Liability Strategies and the Costs of Legal Controls
}

\author{
Reinier H. Kraakman $\dagger$
}

Debate continues over how best to tap the private interests of enterprise participants to serve the public interest. In large part, proponents and critics of structural reform in corporate governance remain divided over whether participants within the enterprise or external institutions should define and police "responsible" corporate activity." Yet, questions concerning the self-regulatory potential of the enterprise are not limited to the corporate governance debate: They also surface in modest guise even within the existing framework of corporate regulation, a framework that relies primarily on corporate profit seeking under external legal constraints. In this more limited context, the question becomes how external controls ought to be crafted and enforced, and whom they ought to target. When, for example, can we rely on liability rules directed solely at the corporation to assure compliance with legal norms? When should we impose absolute legal duties and sanctions on individual participants in the firm as well? To analyze these narrower questions of self-regulatory capacity, we must go beyond a simple description of the formal duties that the law imposes on corporate participants. We must also ask how existing legal duties affect the actual incentives of corporate participants, and whether they do so in ways that yield the "right" amount of compliance

$\dagger$ Assistant Professor of Law, Yale University. I wish to thank Bruce Ackerman, Guido Calabresi, Ronald Gilson, Henry Hansmann, Andrew Houston, Catherine Krupnick, Jerry Mashaw, Robert Prichard, George Priest, Victoria Rostow, and Peter Schuck. I also received helpful comments on an earlier version of this Article from participants in the European University Institute's Colloquium on Corporate Social Responsibility, Directors' Duties, and Liabilities, held in Florence, Italy, in April 1983. The papers delivered at that conference are on file with the author and will be published in Corporate Governance and Directors' Liabilities: The Legal, Economic, and Sociological Analysis of CoRporate Social Responsibiltty (K. Hopt \& G. Teubner eds. 1984).

1. See, e.g., R. Nader, M. Green \& J. Seligman, Taming the Giant Corporation (1976); C. StONE, Where THE LAw ENDS (1975); Braithwaite, Enforced Self-Regulation: A New Strategy for Corporate Crime Control, 80 Mich. L. REv. 1466 (1982); Coffee, Beyond the Shut-Eyed Sentry: Toward a Theoretical View of Corporate Misconduct and an Effective Response, 63 VA. L. REv. 1099 (1977); Engel, An Approach to Corporate Social Responsibility, 32 STAN. L. REv. 1 (1979); Mashaw, The Economic Context of Corporate Social Responsibility, in Corporate Governance and Directors' Liabilities: The Legal, Economic, and Sociological ANalysis of CorpoRATE Social Responsibility (K. Hopt \& G. Teubner eds. 1984) [hereinafter cited as EUI PAPERs]; Stone, Public Enterprise Representation: Economic and Social Policy Inside the Enterprise, in EUI PAPERs, supra; Teubner, Corporate Fiduciary Duties and Their Beneficiaries: A Functional Approach to the Legal Institutionalization of Corporate Responsibility, in EUI PAPERS, supra. 
with legal rules-bearing in mind that enforcing these duties is itself costly. ${ }^{2}$

In this Article, I discuss the circumstances under which liability rules should directly target the incentives of leading corporate participants to control corporate wrongdoing. Although my primary concern is with the conduct of large firms, I focus on the key actors who possess significant influence on business decisions in all firms, both large and small. These actors always include senior executives, who assume the risk of illegal conduct on behalf of the firm; in addition, they may include influential outsiders-directors, attorneys, accountants, and others-who are in a position to veto corporate delicts. In Parts I and II, I argue that enterprise liability rather than individual liability is, and ought to be, the dominant regime for controlling corporate malfeasance except when it leads to underenforcement of legal norms. In Parts III through V, I isolate three such occasions-which I style asset insufficiency, sanction insufficiency, and enforcement insufficiency-and explore their implications for corporate regulation through the imposition of liability upon enterprise participants.

\section{Regimes of ENTERPRise Liability and DuAl Liability}

The iron law of tort and criminal liability for corporate delicts is this: Liability risks, if left unchannelled, ordinarily attach to the legal entity (the corporation) rather than to its officers, employees, or agents. Nowhere does this law operate more forcefully than in the relationship between the firm and its top managers, who routinely enjoy sweeping liability insurance or indemnification benefits at corporate expense. At first glance, such private risk shifting seems to erode the very foundations of legal duty, because personal risk is inseparable from incentive and even "responsibility." Its logic becomes apparent, however, if we trace its role within the broader system of private controls on firm activity.

\section{A. De Facto Unitary Liability Through Risk Shifting}

In theory, the basic principles of agency law establish a regime of "dual liability," in which both the firm and its culpable agents share potential liability for most corporate activities that injure third parties. The common law doctrine of respondeat superior ${ }^{3}$ and its statutory equivalents as-

2. See, e.g., Becker, Crime and Punishment: An Economic Approach, 76 J. Pol. EcoN. 169 (1968); Easterbrook, Criminal Procedure as a Market System, 12 J. LeGal. STUd. 289 (1983).

3. See Restatement (SEcond) of Agency \$§ 212-13, 215, 217B, 219 (1958); Developments in the Law-Corporate Crime: Regulating Corporate Behavior Through Criminal Sanctions, 92 HARv. L. REv. 1227, 1247-51 (1979) [hereinafter cited as Corporate Crime]. 
sure that firms and their agents are ordinarily jointly and severally liable for fault-based civil damages. Similarly, the dominant regime of liability in criminal law holds both the firm and the agent responsible for crimes committed within the scope of the agent's employment."

In practice, however, much of this dual structure collapses. Subsidized insurance, routine indemnification, and the preferences of prosecutors and aggrieved plaintiffs $s^{\mathbb{b}}$ combine to assure that the enterprise's culpable agents bear little direct legal risk except for the most egregious offenses. Regardless of the dictates of formal doctrine, the actual distribution of legal risks more closely approximates a unitary regime of enterprise liability than a dual regime of firm and personal liability. The corporation typically bears the brunt of tort damages or criminal penalties arising out of the activities of its agents or employees. Except in the most serious cases, culpable corporate agents are monitored and sanctioned internally: The firm may fire, demote, or otherwise discipline managers or employees whose actions create unacceptable legal risks.

This pervasive risk shifting raises two questions that are central to our understanding of the functions of dual liability. When we allow such risk shifting, what enforcement function remains for individual liability? Alternatively, when we constrain individual risk shifting and compel corporate agents to bear "absolute" personal liability for their delicts, what enforcement advantages do we gain or lose? ${ }^{8}$ The personal liability of senior corporate managers and directors poses these questions in a particularly forceful, albeit paradoxical, way. Imposing absolute liability on actors at the apex of the corporate hierarchy seems most likely to serve as an effective control over organizational conduct. Yet it is precisely here, among top corporate decisionmakers, that contractual devices and legal policies function most effectively to deflect personal legal risks. Further considera-

4. See, e.g., United States v. Cincotta, 689 F.2d 238, 241-42 (1st Cir.), cert. denied, 103 S. Ct. 347 (1982); 18 U.S.C. § 2 (1982); Ill. Rev. Stat. ch. 38, § 5-4 (1981); N.Y. Penal Law § 20.20 (McKinney 1975 \& Supp. 1984); Corporate Crime, supra note 3, at 1247.

5. Although public enforcement officials and plaintiffs may find the option of pursuing individual managers a comforting fallback or a useful lever in discovery and settlement proceedings, see infra pp. 888, 890-91, it is an option whose full exercise is frequently costly and sometimes illusory. Beyond requiring proof of the culpability of the firm for the delict at issue-which enterprise liability also demands - managerial liability ordinarily forces plaintiffs to disentangle the web of decisionmaking responsibility within the firm. At best, this requires additional effort; at worst, it may be fruitless, when, for example, delicts are the outcome of aggregate conduct for which no one is individually culpable. See Coffec, "No Soul To Damn; No Body To Kick": An Unscandalized Inquiry Into the Problem of Corporate Punishment, 79 MICH. L. REv. 386, 395-97 (1981); Kornhauser, An Economic Analysis of the Choice Between Enterprise and Personal Liability for Accidents, 70 CALrF. L. REv. 1345, 1370-73 (1982); Stone, The Place of Enterprise Liability in the Control of Corporate Conduct, 90 YALE L.J. 1, 31 (1980).

6. These questions have only recently begun to receive careful theoretical attention in a variety of contexts. See Posner, Optimal Sentences for White-Collar Criminals, 17 AM. CRIM. L. Rev. 409 (1980); Sykes, The Economics of Vicarious Liability, 93 YALE L.J. (1984) (forthcoming); sources cited supra note 5 . 
tion of this apparent paradox, however, reveals the cost advantages of "pure" enterprise liability as an enforcement device over a wide range of firm delicts.

Consider first the chief element of the paradox: the insulation afforded corporate directors and top managers from personal risk for firm wrongdoing. Even in the absence of any contractual devices to shift risk from corporate management, the basic forms of legal duty evidence a protective skew. Neither the doctrine of respondeat superior nor the corporate fiduciary's duty of care ${ }^{7}$ seriously restrict the top manager's most powerful risk-shifting tool-delegating legally risky policies to subordinates. ${ }^{8}$ With few exceptions, public enforcement officials or private victims can obtain judgments against a manager only for his personal conduct; ${ }^{\theta}$ power within the firm does not generate a legal "duty to supervise" subordinates' conduct. Similarly, the business judgment rule insulates officers and directors from liability to the corporation for the failure to institute managerial controls that might have avoided legal injury. ${ }^{10}$ Thus, absent allegations of

7. Corporation law imposes a duty on managers and directors to exercise reasonable care in the discharge of their corporate duties. See, e.g., N.Y. Bus. CoRP. LAw $\S 717$ (McKinney 1977); Model. Business Corp. Act $\$ 35$ (1979). See generally W. Cary \& M. Eisenberg, Cases and MateriALS ON CoRPORATIONS 518-62 (5th ed. 1980) (discussing duty of reasonable care).

8. Respondeat superior channels liability to the firm rather than to its controlling managers. See supra note 3. Corporate directors and officers ordinarily satisfy their duty of care to shareholders when they rely on the honesty and integrity of their subordinates; they need not establish monitoring procedures when there is no reason to suspect subordinate wrongdoing. See Graham v. Allis-Chalmers Mfg. Co., 41 Del. Ch. 78, 188 A.2d 125 (1963). For contrasting attempts to delineate monitoring duties, see Foreign Corrupt Practices Act of 1977; § 102, 15 U.S.C. $\S 78 \mathrm{~m}(\mathrm{~b})(2)$ (1982) (imposing duty to maintain system of internal accounting controls on firms); ALI, PRINCIPLES OF CoRPORATE Governance and STRuCture: Restatement and Recommendations II 4.01(b) (Tent. Draft No. 1, 1982) (duty of care includes reasonable concern "with the existence and effectiveness of monitoring programs, including law compliance programs"); see also infra note 10 (discussing business judgment rule).

9. Put somewhat differently, managers and directors enjoy de facto insulation from liability-even apart from risk-shifting agreements-because of the organizational buffer between themselves and lower-level employees who implement their decisions. Managers are personally liable for decisions that are negligent or criminal on their face, just as any citizen would be. But when the firm's top-level policies merely impose a risk-even a high risk-of wrongdoing, the top executives or directors responsible for the decision generally escape liability for the consequences because the law assumes that they intended their policies to be implemented in a "reasonable" and legal fashion. Of course, legislation may occasionally expand managerial liability for particular organizational delicts; top managers are assigned a special duty to supervise subordinates or even a strict duty to prevent certain criminal delicts entirely. See, e.g., United States v. Park, 421 U.S. 658 (1975) (imposing strict criminal liability on firm's president for unsanitary warehouse conditions); Energy Reorganization Act of 1974, $\S \S 206$, 208, 42 U.S.C. $\$ \S 5846,5848$ (1976) (imposing duty to report any noncompliance with Atomic Energy Act requirements or any abnormal occurrences at nuclear facility on both "individual director[s]" and "responsible officer[s]"); Federal Water Pollution Control Act of 1972, § 2, 33 U.S.C. $\S \S$ 1317 (d), 1318 (1976) (unlawful for owner or operator of source to operate in violation of effluent standard and imposing penalties on owners for failure to supervise).

10. See Joy v. North, 692 F.2d 880, 886-87 (2d Cir. 1982), cert. denied, 103 S. Ct. 1498 (1983); Gilson, A Structural Approach to Corporations: The Case Against Defensive Tactics in Tender Offers, 33 Stan. L. Rev. 819, 822-24 (1981). But see McDonnell v. American Leduc Petroleums, Ltd., 491 F.2d 380, 384-85 (2d Cir. 1974) (business judgment rule does not protect from extreme or 
self-dealing or other intentional disloyalty to the firm, top corporate officials are ordinarily at risk for the firm's injury of outsiders only when they are singled out in a cause of action by third-party victims or enforcement officials and only for injuries inflicted by their personal conduct.

Even this limited range of potential liability, however, attaches significant personal liability to business decisions that would continue to weigh heavily on managers and directors but for the institution of contractual risk shifting. Top corporate officials can, and routinely do, procure indemnification ${ }^{11}$ or liability insurance ${ }^{12}$ for virtually all legal risks incurred on

lengthy failure to manage); Litwin v. Allen, 25 N.Y.S.2d 667 (Sup. Ct. 1940) (egregious carelessness falls outside scope of business judgment rule).

Although managers cannot be indemnified against damages arising from a breach of duty to the corporation, see infra note 11, much of this risk is deflected by the business judgment rule. This rule effectively creates a judicially imposed, standard-form, indemnification contract, which automatically relieves the board-and, by extension, top managers who act with its approval-from liability to shareholders for less egregious forms of personal negligence. Indeed, the business judgment rule is even more protective than a right to indernnification because it also protects against managerial liability to creditors when the firm is bankrupt. Only personal liability insurance can insulate as effectively as the business judgment defense. See infra note 12 (discussing liability insurance). One reason for acquiring such insurance is precisely that it covers the tiny risk of personal liability for negligent breach of the manager's duty of care to the corporation which is not otherwise deflected by the business judgment rule. See Bishop, Sitting Ducks and Decoy Ducks: New Trends in the Indemnification of Corporate Directors and Officers, 77 YALE L.J. 1078, 1095 (1968).

11. See J. Bishop, The Law of Corporate Officers and Directors: Indemnification AND INSURANCE \6.03[7] (1981).

Delaware, for example, permits indemnification for the costs of defending against, and the liability resulting from, third-party suits if the officer, director, or corporate agent "acted in good faith and in a manner he reasonably believed to be in or not opposed to the best interests of the corporation, and, with respect to any criminal action or proceeding, had no reasonable cause to believe his conduct was unlawful." DeL. CODE ANN. tit. 8, § 145(a) (1983); see MODEL BusINEss CoRP. ACT § 5(b) (1982). Delaware also allows the indemnification of a director, officer, or agent for the cost of defending against a shareholder suit if he or she acted in good faith and not in opposition to the corporation's interests and was not negligent or responsible for other misconduct related to his or her corporate duties. DeL. Code ANn. tit. 8, § 145(c) (1983). The pre-1982 Model Act and the laws of some 21 states closely follow Delaware on these points, J. BISHOP, supra, I 6.03, while other state indemnification statutes are more restrictive in varying degrees, id. I $6.05[1]-6.05[10]$.

State law indemnification provisions are even less restrictive than they initially appear. Delaware and the states following the former Model Act have so-called "nonexclusive" statutes, which allow indemnification to extend beyond the limits ostensibly fixed by the statute if authorized by a by-law, contract, or vote of disinterested directors or shareholders. See DEL. CODE ANN. tit. 8, \& 145(f) (1983); MOdel Business Corp. Act § 5(f) (1979). But see Model Business Corp. ACt § 5(g) (1982) (making Model Act provisions exclusive). Thus, the ultimate limits of permissible indemnification are left to public policy, as guided (but not fixed) by the express provisions of these acts. See Bishop, supra note 10, at 1085-86. Even more important, state law typically leaves the decision whether to indemnify to a quorum of disinterested directors or independent legal counsel. See, e.g., Del. Code ANn. tit. 8, § 145(d) (1983); Model Business CorP. ACT § 5(e) (1982). This suggests that porous statutory restrictions on indemnification are ordinarily construed broadly. See Bishop, supra note 10, at 1079; Stone, supra note 5, at 50.

12. The corporate law of Delaware and of the majority of states following the former Model Act appears to allow insurance for the liability of corporate insiders even when liability arises from acts committed willfully or in bad faith. See DEL. CODE ANN. tit. 8, § 145(g) (1983) (allowing insurance even when indemnification is not permitted); MODEL BusINESS CORP. ACT $\$ 5(\mathrm{~g})(1979)$ (same). Commercially available directors' and officers' liability insurance policies, however, exclude such acts from their coverage. See J. BisHop, supra note 11, II 6.06[1]. In any event, insurance against liability for acts taken in bad faith might be unenforceable on public-policy grounds. Id.; see Stone, supra note 5, at 52. As a practical matter, insurance functions primarily to reimburse the corporation for its 
behalf of the firm except those generated by intentional torts or knowing criminal conduct. Thus, corporate officials can shift even the risks of punitive liability or criminal fines as long as these risks arise from actions taken in good faith and without "reasonable cause" to know of their illegality.

Hence the preliminary question: Why do we tolerate such massive shifting of personal legal risks? The answer might seem simple if risk shifting were restricted to liability for ordinary negligence. Here, the law might arguably seek only the compensation of injury and not the deterrence of specific conduct. ${ }^{13}$ But contractual risk shifting in the realm of explicit regulation and punitive liability requires stronger justification. Here, we do care who pays the penalty, at least insofar as we wish to deter would-be wrongdoers. Risk shifting can be defended as a matter of legal policy, then, only if absolute personal liability does not contribute to deterrence, or if its contribution-however great-is offset by the costs imposed on innocent firms and managers. In fact, risk shifting by corporate officials frequently meets one or both of these criteria. A brief sketch of the roles of shareholders and managers in the publicly held corporation shows why.

\section{B. The Manager-Firm Relationship}

The modern theory of the firm depicts the corporation as a nexus of contracts among the suppliers of firm inputs-labor, capital, specialized services, and the like. ${ }^{14}$ In this view, the separation of ownership from control is a natural division of the entrepreneurial function into its two constituent elements, risk bearing and management. ${ }^{15}$ As claimants on the firm's earnings after other enterprise participants have been paid, shareholders absorb the bulk of the net gains or losses from firm projects as long as the firm remains solvent. The equity contract is ideally suited for this risk-bearing function, particularly if shares trade in an active securities market. Limited liability assures that shareholders retain an unlimited claim to the profits of successful firms but never risk more than the value of their shares in unsuccessful ones. ${ }^{16}$ Moreover, an active securities mar-

indemnification expenses and to protect officers and directors directly on occasions when the corporation will not, or cannot, do so. See Bishop, supra note 10, at 1087-89.

13. Of course, imposing liability for ordinary negligence is usually said to serve a deterrent or regulatory function as well. Therefore, we may well care who pays the damages, if we want to deter or regulate particular parties. See G. CALABresi, The Costs of Accidents 68-94 (1970) (discussing "general deterrence").

14. See, e.g., Fama, Agency Problems and the Theory of the Firm, 88 J. PoL. Econ. 288 (1980); Jensen \& Meckling, Theory of the Firm: Managerial Behavior, Agency Costs and Ownership Structure, 3 J. Fin. Econ. 305 (1976).

15. See Fama, supra note 14, at 289-90.

16. For financial purposes, the limited-liability feature of the equity contract permits recharacter- 
ket permits shareholders to diversify their investment portfolios at low cost. By holding shares in many different firms, they can protect against and possibly offset losses arising from the poor performance of any single firm. ${ }^{17}$

Counterbalancing these advantages, however, are the familiar costs of an agency relationship. Dispersed, diversified, and disorganized shareholders must entrust the operation of the firm to managers. But unless these managers are also principal shareholders, their interests will not dovetail with those of the shareholders. Managers' interests will instead depend on the corporation's return to their own specialized "investment" of time, skill, and reputation. Thus, managers will manage with an eye to increasing their own expected utility by maximizing future compensation including salary, job tenure, promotion prospects, informal perquisites, and opportunities for consuming leisure and other goods on the job.

There are, of course, important limits on how far managerial policies can deviate from the shareholders' interests. Senior managers will have an incentive to police the deviations of their juniors. Overlapping contract and market controls help align shareholder and managerial interests at the apex of the corporate hierarchy even if top managers are not major shareholders. Bonuses and stock option plans, for example, link managerial compensation to firm performance; salaries are open to periodic renegotiation; and exceptional managerial service may find its reward in a better reputation or in job offers from other firms, just as poor performance can jeopardize tenure by triggering termination, takeovers, proxy fights, or, in the extreme, the bankruptcy of the firm itself. ${ }^{18}$

ization of the shareholders' interest as a call option. Shareholders can be said to "sell" the firm to its creditors subject to the right to repurchase it by meeting the terms of its indebtedness. As with any call option, risk is limited by share price but the potential for gain is unlimited. See R. BrealeY \& S. Myers, Principles of Corporate Finance 430-31; Gilson \& Kraakman, The Mechanisms of Market Efficiency, 70 VA. L. REv. (1984) (forthcoming).

17. For a useful introduction to diversification and capital-asset pricing, see R. BREALEY \& S. MYERS, supra note 16, at 112-56. Portfolio diversification only eliminates "unsystematic risks," that is, risks that are associated with particular firms. The price of shares must reflect the firm's sensitivity to "systematic risk" that affects all market assets. See id. at 121. Legal risk is the paradigmatic unsystematic risk, in contrast to, for example, general economic trends which affect all firms in varying degrees.

18. See, e.g., Fama, supra note 14, at 292, 296-302; Manne, Mergers and the Market for Corporate Control, 73 J. Pol. Econ. 110, 112-13 (1965).

As Fama observes, market controls on managerial performance overlap. The financial market, product market, and market for corporate control reveal the weaknesses of management teams and can hasten their displacement. But the most important disciplining factor is the operation of the market in managerial services. The service market involves both attempts to shape a manager's incentives by contract at the time he or she is hired and periodic wage adjustments (either within or outside the firm) which penalize a manager's revealed propensities to consume at shareholder expense. See Fama, supra note 14, at 295-97. While some after-the-fact settling up undoubtedly occurs, few observers would venture as far as Fama in relying on the efficiency and monitoring abilities of managerial labor markets to resolve incentive problems, especially for top managers. For a skeptical perspective on 
Even at their best, however, these controls create only imperfect correlations among the efforts of individual managers, the marginal return from those efforts to the firm and its shareholders, and the ensuing reward to the managers. Monitoring and evaluating the performance of top managers are simply too difficult to permit anything like a total convergence of interest between managers and shareholders. ${ }^{19}$ In addition, managers have good reason to eschew full participation in the fruits-both bitter and sweet-of their efforts. Unlike shareholders, managers are undiversified risk bearers who invest their services in only one firm at a time. Thus, they will tend to evaluate firm projects with a risk-averse bias unless they are paid to do otherwise. Although compensation incentives and the lure of career enhancement may partially offset this bias, they are unlikely to overcome it entirely, even under intense market pressures. Performance measures for top managers are too crude; the dangers of provoking too much risk taking or other strategic behavior are too great; and the empirical consequences of alternative incentive schedules are too poorly understood. ${ }^{20}$

\section{The Efficiency of Risk Shifting}

This thumbnail account of the respective risk-bearing abilities of shareholders and hired managers points to the chief cost advantage of permitting corporate officials to shift personal legal risk. Senior executives bear legal risk as inefficiently as they bear other forms of firm-specific corporate risk.

Under a de jure regime of dual liability, even law-abiding corporate managers routinely incur legal risks. Personal liability may follow from mistake or simple ignorance when legal rules are complex, ambiguous, or novel. A recent survey, for example, found that as many as half of all small businessmen are unfamiliar with federal or state regulations on hazardous waste disposal. ${ }^{21}$ Moreover, bold decisions may misfire and seem negligent or worse in hindsight. Perhaps most importantly, lucrative busi-

market controls, see Vagts, Challenges to Executive Compensation: For the Markets or the Courts?, 8 J. Corp. L. 231, 234-45 (1983).

19. See Jensen \& Meckling, supra note 14, at 306-07 (discussing irreducible agency costs). Note in particular that securities prices, which value the firm's total returns, suffer a serious shortcoming as a means of rewarding managerial performance: They do not reflect the nonsystematic risks of firm projects. See Diamond \& Verrecchia, Optimal Managerial Contracts and Equilibrium Securities Prices, 37 J. Fin. 275, 283 (1982); Ramakrishnan \& Thakor, The Valuation of Assets Under Moral Hazard, 39 J. Fin. 229, 232-34 (1984).

20. See Vagts, supra note 18 . For a highly readable account of the difficulty of crafting performance measures, the inherent tension between finely tuned incentive plans and the risk preference of "investors" of human capital, and the consequences of these factors for the structure of law firms, see Gilson \& Mnookin, Sharing Among the Human Capitalists: An Economic Inquiry Into the Corporate Law Firm and How Partners Split Profits, 37 StAn. L. Rev. (1985) (forthcoming).

21. See Small Business, Wall St. J., July 25,1983 , at 13 , col. 1. 
ness projects of borderline legality may be worth the wager to the firm even though they impose legal risks on managers. A now-standard illustration is the legal gamble taken by managers of high-technology firms who opt to enter joint ventures in research and development despite the uncertain proscriptions of the Sherman Act. ${ }^{22}$

If these sorts of personal legal risks are inevitable, however, competent corporate decisionmakers will either demand insulation from them or require compensation for bearing them. As undiversified risk bearers who gamble all their personal assets, uninsured managers will of course demand a very large risk premium if they are simply paid outright for enduring even a small probability of catastrophic personal liability. But if these same managers are able to shift their personal risks through indemnification or insurance, then the net cost to the firm of these nominally "personal" risks will be much lower. Both shareholders and insurers are diversified risk bearers. Each need be concerned only with a predictable average of liability costs across numerous firms and managers rather than with the unsettling prospect of a single ruinous legal action. Finally, insurance or indemnity agreements reduce a firm's agency costs as well. Compensating managers directly for their job-related liability risks would add a dimension of complexity to the already difficult problem of monitoring and evaluating their performance. Even the most elaborate compensation schemes may not overcome a risk-averse manager's temptation to "cheat" shareholders by surreptitiously choosing business strategies that are less profitable to the firm but less risky for its managers. ${ }^{23}$

Any prohibition of managerial risk shifting must assume, then, that the ability to alter the personal incentives of corporate decisionmakers directly provides an additional control over firm conduct that justifies the attendant increases in the costs of firm management. In essence, a manager's

22. See Antitrust Law Limits Proposed, N.Y. Times, Mar. 30, 1983, at D1, col. 1 (reporting plan to cut back availability of treble-damage antitrust awards in order to end overdeterrence of beneficial joint development ventures); $f f$. United States v. United States Gypsum Co., 438 U.S. 422, 440-41 (1978) (discussing notorious difficulty of distinguishing antitrust offenses "from the gray zone of socially acceptable and economically justifiable business conduct").

23. Cf. infra p. 881 (discussion of perverse incentive for agents to take premium for risk and then engage in low-risk activity).

Recent discussion of perverse incentives that lead agents to engage in overly risk-averse behavior also appears in the literature dealing with the personal liability of public officials. See, e.g., P. Schuck, Suing Government: Citizen Remedies for Official Wrongs 68-77 (1983) (discussing how risk aversion is manifested through delay, inaction, and formalism); Mashaw, Civil Liability of Government Officers: Property Rights and Official Accountability, LAw \& CoNTEMP. ProBs., Fall 1978, at 8, 26-33 (discussing effects of personal liability on officials' behavior). Schuck, in particular, argues that the absence of competitive discipline and of opportunities for effective monitoring renders this problem especially severe in the public sector. P. ScHuck, supra, at 8-12, 136-46. When the doctrine of "sovereign immunity" limits liability for governmental torts exclusively to culpable agents, the problems may be exacerbated. See P. ScHUck, supra, at 89-99; Mashaw, supra, at 14-22, 26-29. In such cases, we may be faced with a special form of sanction insufficiency. See infra pp. 878-90 (discussing sanction insufficiency). 
risk-bearing costs and a firm's agency costs are the specialized compliance costs peculiar to dual liability. All firms must bear them, since even lawabiding managers face the prospect of offending by mistake. Additional deterrence is always purchased at a price.

The key issue is whether the benefit-fewer offenses-can be purchased more cheaply. If we need additional control over a firm's conduct, why should we resort to absolute personal liability rather than to more severe sanctions on the enterprise alone? Even if contract and market controls do not fully align managerial interests with those of the corporation, enterprise liability holds out the same promise as personal liability of prodding corporate officers into following socially desirable policies. ${ }^{24}$ Hefty damage awards or fines will reduce a firm's earnings-and therefore managerial rewards-at least as much as routine business losses of a comparable magnitude, and probably even more. In addition, unlike managerial self-dealing, typical corporate offenses such as antitrust violations, tax evasion, or hazardous waste dumping are undertaken to benefit the corporation rather than to benefit its managers directly. Except on rare occasions, managers stand to gain only when the firm itself stands to gain. ${ }^{25}$

Taken together, these considerations suggest that absolute managerial liability does not necessarily provide enough additional deterrence to offset the greater costs that it imposes on regulated firms. Although enterprise penalties alone can influence managers only indirectly, they remain potent

24. Even if these controls are not frictionless, see supra p. 866 , they may effectively deter firm delicts that offer no particular benefits to managers. See generally Sykes, supra note 6 (discussing enterprise controls on agents).

25. As an initial approximation, this genre of business delict may be said to resemble other highly risky firm projects: Hired managers benefit from such delicts only indirectly, through increased compensation for managerial services. If contract and market controls on compensation are weak, then managerial risk taking will be poorly correlated with compensation, and-at the top level of the firm, at least-there will be no business-related incentive for taking legal risks; those that are taken will serve primarily to gratify personal tastes. Indeed, secure managers who can "write their own ticket" might be expected to search for ways to improve-rather than to jeopardize-their reputations for responsible business practices. $C f$. Engel, supra note 1, at 56-58 (discussing how manager-shareholder agency problem influences "corporate social responsibility"); Mashaw, supra note 1, at 11-12 (same). By contrast, where contract and market controls tie management compensation tightly to firm performance, managers will ordinarily undertake clear-cut legal delicts on behalf of the firm only when the firm stands to benefit.

Exceptions will arise if managers can manipulate the link between compensation and firm performance. In the simplest case, managers who face imminent replacement-due, for example, to poor performance-may take "irrational" legal risks on behalf of the firm because they have nothing to lose by doing so. In more complex variations of this "final-period problem," managers with high personal discount rates or short expected job tenures might be tempted by illegal strategies that yield long-term expected losses for the firm-a pattern that may arise if the offense is initially profitable but eventually subject to heavy sanctioning. Finally, at the middle levels of the corporate hierarchy, highly variable compensation schemes that penalize poor performance often trigger illegal activity as a response to firm controls. See Coffee, supra note 5, at 397-99; Ross, How Lawless Are Big Companies?, ForTune, Dec. 1, 1980, at 64. 
incentives in the absence of any offsetting managerial advantage from offending conduct. Yet, precisely because enterprise liability does work with little personal risk to managers, it induces compliance without complicating the manager-shareholder contract or disturbing the advantageous intra-firm allocation of business risk. It follows that enterprise liability is the normal form of corporate liability in the prescriptive as well as the descriptive sense, and that managerial liability should be viewed as an ancillary form-as a kind of backstop for occasions when enterprise liability is likely to fail. ${ }^{28}$

\section{Failures of Enterprise Liability and Strategies of MANAGERIAL LIABILITY}

Enterprise liability "fails" as a regime of legal control when the aggregate costs of using enterprise liability alone exceed the costs of imposing the risk of liability upon both firms and agents. In Part I, I argued that managerial liability for firm delicts ordinarily increases the cost of legal controls for firms and their shareholders. By contrast, a failure of enterprise liability typically occurs when contractual risk shifting increases costs to third parties-either the victims of firm wrongdoing or the public enforcement agencies charged with its prevention.

These costs usually take the form of harm that would have been avoided either by deterrence or by compensation if corporate decisionmakers bore the full legal risk of their conduct. Yet these costs may also assume the form of increased expenditures on enforcement. For example, public enforcement officials may be compelled to spend more on detecting and prosecuting offenses in order to ensure that the numbers of offenses remain at a tolerable level in the absence of personal liability. To the extent that these costs of additional enforcement exceed the risk-shifting gains of firms or managers, enterprise liability has failed even though resort to absolute personal liability would not have further lowered the prevailing level of wrongdoing. But, regardless of whether the failure of enterprise liability appears as increased enforcement costs or as the harm inflicted by offenses that might have been avoided, it involves costs that by definition cannot be reduced by increasing the firm's expected liability.

This insight permits a useful classification of three overlapping forms of the failure of enterprise liability in terms of the character of the constraint on increasing the liability of the firm. These failures are (1) asset insufficiency, when firms lack the assets to pay the law's price for their delicts; (2) sanction insufficiency, when the legal system cannot charge a price high enough to deter firm delicts for whatever reason, including asset in-

26. See Stone, supra note 5, at 11-18. 
sufficiency; ${ }^{27}$ and (3) enforcement insufficiency, when the legal system cannot even detect or prosecute a significant proportion of offenses. Each failure of enterprise liability, in turn, suggests a particular strategy for managerial liability. Personal liability that can be shifted contractually by insurance or indemnification functions primarily as a safeguard against asset insufficiency. Absolute or unshiftable liability serves largely to remedy sanction insufficiencies when it is imposed on managers who control firm delicts. But when it is imposed on potentially powerful corporate outsiders who cannot control illegal conduct directly-who can do no more than monitor for, and attempt to veto, such conduct-absolute liability in effect delegates enforcement to these private actors, or "gatekeepers," and thus serves to remedy enforcement insufficiencies by conscripting deputies within the enterprise. ${ }^{28}$ These functional relationships, which I explore in the following sections, are summarized in Figure 1.

FIGURE 1

Strategies of MaNagerial Liability

\begin{tabular}{c|c|c|c}
\hline \hline $\begin{array}{c}\text { TYPE OF } \\
\text { ENTERPRISE } \\
\text { LIABILITY FAILURE }\end{array}$ & $\begin{array}{c}\text { Asset } \\
\text { Insufficiency }\end{array}$ & $\begin{array}{c}\text { Sanction } \\
\text { Insufficiency }\end{array}$ & $\begin{array}{c}\text { Enforcement } \\
\text { Insufficiency }\end{array}$ \\
\hline TYPE OF & & & \\
MANAGERIAL & Shiftable & Control & $\begin{array}{c}\text { Gatekeeper } \\
\text { Liability } \\
\text { LIABIIITY }\end{array}$ \\
\hline \hline
\end{tabular}

\section{Shiftable Liability and Asset InSUfficiency}

When it is sensible to allow indemnification and insurance for managers, why impose managerial liability at all? Why not offer managers the same immunity from personal liability arising from suits by third parties that shareholders enjoy from all corporate legal risk or that managers enjoy from shareholder actions under the business judgment rule ${ }^{29}$ The best answer may be that the personal liability of firm agents-and in particular, of managers and directors-can serve as a partial check on asset insufficiency, that is, on the danger that undercapitalized corporations will

27. The legal system may not be able to set a sufficient price in either of two senses: There may be constraints on effective enterprise penalties, see infra pp. 883-86, or, even if there were no such constraints, higher enterprise penalties might simply be less cost-effective than the alternative of absolute managerial liability, see infra pp. 887-90.

28. Potential targets of gatekeeper liability include outside directors, lawyers, accountants, and underwriters. See infra p. 892. These "outsiders" can simultaneously serve as "internal" monitors of firm behavior-even though they often are not, technically speaking, firm employees-because they possess privileged information about firm operations which is inaccessible to public enforcement officials.

29. See supra p. 862 (business judgment rule); p. 864 (limited shareholder liability). 
abuse their limited assets to evade the compensatory or deterrent policies of liability rules. ${ }^{30}$

\section{A. Managerial Liability as Protection Against Asset Insufficiency}

The simplest form of asset insufficiency arises when the firm's assets cannot cover tort damages for a firm's delicts. Although this form of asset insufficiency has historically been a problem in small, owner-managed firms that can be abandoned at relatively low cost, the recent advent of enormous damage awards in products liability, securities, and antitrust actions indicates that larger, publicly held corporations are also vulnerable to asset insufficiency. ${ }^{31}$

In general terms, the way in which managerial liability might protect against asset insufficiency is readily apparent. The victims of corporate torts are involuntary creditors of the firm who, like any other unsecured creditors, are subject to strategic evasion by shareholders. Just as shareholders can displace general business risks onto senior security holders either by accumulating new debt or by increasing the risk of the firm's portfolio of business projects, so too shareholders can displace the expected costs of legally risky or proscribed conduct either by operating the firm with net assets well below the level of its potential tort liabilities or by increasing the legal risk assumed by the firm. ${ }^{32}$ Unlike senior security

30. Shiftable managerial liability might alternatively be viewed as a benefit to the firm. First, it allows firms to hire agents whose personal liability serves to deter them from making overly risky decisions. Second, it permits firms some discretion to indemnify selectively, that is, to compensate officers for damages imposed on them only when it appears in hindsight that liability was incurred in the firms' best interests. The very breadth and leniency of risk-shifting practices, see supra pp. 861-64, suggests, however, that firms rarely employ the risk of personal liability for corporate torts as a device for regulating managerial behavior.

31. See, e.g., Coffee, supra note 5, at 390-93 (viewing asset insufficiency as "deterrence trap"); Hall, The Problem of Unending Liability for Hazardous Waste Management, 38 Bus. LAw. 593, 595 (1983) (discussing huge joint and several liability under Superfund legislation). The increasing size of commercial liability claims has led to a further development that threatens to increase the risk of corporate asset insufficiency: a fundamental shift from "occurence" to "claims-made" basic liability insurance policies. An occurence policy-until recently the commercial standard-covers liability due to events which occur during the period when a policy is in force, regardless of when liability for those events is imposed. A claims-made policy, however, covers only liability which arises during the life of the policy. It does not cover losses caused by events which occurred while the policy was in force but whose effects-and the legal responsibility for those effects-occur after the policy has lapsed. Thus, claims-only coverage permits insurance companies to limit exposure and raises the possibility that some injuries which manifest themselves long after the event that triggers them will remain uninsured entirely. See Hall, supra, at 617-19; Insurance Industry Is Changing Policy for Basic Business Liability Coverage, Wall St. J., Jan. 5, 1984, at 6, col. 3. See generally Committee on Bus. Mgmt. Liab. Ins., Liability Insurance Against Environmental Damage: A Status Report, 38 Bus. Law 217, 221-31 (1982) (discussing available insurance policies and their relationship to various forms of liability for pollution).

32. The option model of the shareholder's interest, see supra note 16 , clearly shows the equivalence of these two modes of cost externalization. They both increase the volatility of returns on firm assets. Of course, a variety of legal doctrines loosely constrain the shareholders' freedom to undercapitalize the firm relative to its expected tort damages. See Clark, The Duties of the Corporate Debtor 
holders or other contract creditors, however, tort victims and public enforcement officials cannot protect themselves by refusing the firm "credit" or by demanding a security interest in firm property before accidents or offenses. Victims of industrial pollutants, no less than pedestrians injured by reckless cabbies must collect from the firm, its agents, or insurers if they are to collect at all.

Under these circumstances, the imposition of personal liability on a firm's participants can rechannel at least a portion of the expected costs of those business delicts that are attributable to individual agents back to those agents, who in turn may be in a position to contract with the firm or its shareholders. In effect, dual liability gives agents who engage in risky firm projects a potential contract creditor's interest in the corporation's net assets and risks. ${ }^{33}$

It follows that the risk-shifting opportunities that top managers enjoy in the form of indemnification or insurance are anything but obstacles when liability rules seek only to price the harm caused by corporate delicts rather than to bar harmful conduct entirely. Indeed, these opportunities are precisely the vehicles through which agents or employees can force the firm and its shareholders to internalize the expected liability costs that undercapitalization would otherwise impose on tort victims. Indemnity rights are valuable, after all, only to the extent that the firm maintains a level of capitalization or insurance that is commensurate with its agents' risks of personal liability. The purchase of personal liability insurance for agents is simply an alternative method of guaranteeing that the firm's own risks are adequately insured. Subject to the limitations of available insurance policies, plaintiffs can recover from the insured individual if the firm lacks the assets to satisfy a judgment. ${ }^{34}$

From this perspective, the real defect of personal liability as a check on undercapitalization lies in the danger that agents will not pressure the firm into providing adequate coverage of their personal liability risks. If

to Its Creditors, 90 Harv. L. Rev. 505 (1977) (discussing state law capital requirements, fraudulent conveyance laws, equitable subordination, and corporate "veil piercing" doctrine). Only the California courts, however, have gone so far as to suggest that undercapitalization relative to risk may itself be a ground for disregarding the corporate fiction and holding shareholders liable for tort debts. See Minton v. Cavaney, 56 Cal. 2d 576, 579-80, 364 P.2d 473, 475, 15 Cal. Rptr. 641, 643 (1961); W. CARY \& M. EISENBERG, supra note 7, at 95-96 (discussing California's approach). Other states, notably New York, have refused to follow California. See Walkovszky v. Carlton, 18 N.Y.2d 414, 223 N.E.2d 6, 276 N.Y.S.2d 585 (1966).

33. Unsecured contract creditors also have an incentive to monitor the firm's legal risk taking, since in the event of bankruptcy they will participate in the firm's estate with tort creditors on an equal basis. See 11 U.S.C. $\$ 726(a)(2)$ (1982). Unsecured contract creditors, however, are likely to be poorly placed to monitor risk taking in comparison to managers. See Levmore, Monitors and Freeriders in Commercial and Corporate Settings, 92 YALE L.J. 49, 50-59, 76-82 (1982).

34. Liability insurance for corporate officers and directors normally comes in the form of modified claims-only policies. These limit coverage for delayed claims according to a complex formula. See Bishop, Understanding $D$ E $O$ Insurance Policies, HaRv. Bus. Rev., Mar.-Apr. 1978, at 20, 27, 30. 
the firm hires judgment-proof agents at a premium, for example, it merely carries the undercapitalization one step further by exploiting the limited assets of both the enterprise and its risk-taking agents. Worse yet, if the firm's agents lack sufficient information about either the magnitude of their expected liability costs or the firm's ability to offset these costs, they may fail to bargain with the firm for sufficient insulation from personal risk. In this case, agent liability merely shifts the risks of firm activities from one set of inefficient risk bearers to another-from unlucky tort victims to defrauded employees. ${ }^{35}$

Imposing shiftable personal liability on high corporate officials, however, largely avoids these dangers. Unlike lower-level corporate agents, senior managers and directors are ideal targets for incentives aimed at ultimately prodding the firm to cover its potential liability. Their position normally provides them with information about the need for insurance; their power assures that they can act on their knowledge of risk levels; and their personal assets and risk preferences are likely to encourage them to seek adequate insurance coverage. Even when they are not the firm's cheapest harm avoiders, they are likely to be its most reliable insurers. ${ }^{36}$ When these top managers double as the firm's principal shareholders, their incentive to insure against personal liability for firm delicts arising from their own conduct will resemble that of unincorporated partners, who ordinarily insure themselves over the entire range of their firm's tort liabilities. When top managers are not principal shareholders, their demand for insurance may be even greater, since they do not receive the full return of gambling their personal assets unless they are specifically compensated for their risk bearing.

The very fact that hired managers are costly risk bearers, however, militates against such special compensation. The same factors that lead shareholders to prefer providing managers with insurance or indemnification rather than with outright compensation for risks of job-related liability will also discourage managers and shareholders from undercapitalization. Not only is a liability charge against personal assets undiversifiable for both the hired manager and the owner-manager, but the risk-bearing costs of the hired manager also include the contracting and monitoring expenses associated with controlling his or her risk taking. ${ }^{37}$

35. See Halpern, Trebilcock \& Turnbull, An Economic Analysis of Limited Liability in Corporation Law, 30 U. Toronto L.J. 117, 149-50 (1980) (employees are class of corporate creditor which face most severe informational problem).

36. Cf. G. CAlABREsI, supra note 13 , at 50-53 (discussing enterprise liability as an insurance incentive).

37. See supra p. 867. 


\section{B. Comparative Merits of Shiftable Liability as a Response to Undercapitalization}

With this much said, I should hasten to add that the extent of protection against asset insufficiency currently provided by managerial liability is difficult to estimate. ${ }^{38}$ We do know, however, that the existing focus of substantive tort law on the personal conduct of managers and directors seriously limits its role as a safeguard against undercapitalization. Unless the law develops a managerial duty of supervision akin to the duty of care that corporate officials owe to the firm, and makes managers liable to outside tort victims for its breach, managerial liability cannot reach the vast majority of corporate torts for which obvious managerial fault is either entirely absent or inordinately difficult to prove. ${ }^{39}$

The hard question, then, is whether expanded personal liability should be imposed on corporate managers or directors specifically to discourage risk externalization by undercapitalized firms. Any answer to this question implicates, in turn, still other, more basic issues of corporate legal policy. Even setting aside the most basic issue of all-the ultimate wisdom of limited shareholder liability-the list is still formidable. How important is the risk subsidy provided by limited liability to the operation of small and risky firms? How strong are the incentives that it creates to underinvest in safety precautions or legal compliance? And how efficiently could today's insurance markets absorb the risks that firms presently "insure" against simply by limiting their capitalization, especially in the case of small, privately held firms? ?0 $^{\circ}$

Analysis of these issues bearing on the appropriate scope of the "risk subsidy" that limited corporate liability provides must necessarily be left

38. Reports of tort plaintiffs turning successfully to the personal assets of hired managers of large firms after already failing to collect against a bankrupt firm are scarce to the point of non-existence. Yet this fact alone tells us little, since the relevant benchmark is not the frequency with which tort plaintiffs now recover against managers for corporate torts, but rather the frequency with which these plaintiffs might not recover at all under a regime of pure enterprise liability. Even faced with the current possibility of managerial liability, small, owner-managed firms engage in lead smelting and hazardous waste disposal, activities which involve a significant danger of injuring third parties and leaving them uncompensated. See, e.g., Goldfarb, Kepone: A Case Study, 8 EnvTL. L. 645, 658-60 (1978) (discussing how large chemical company resorted to thinly capitalized independent contractor to dispose of kepone); Madlin, Lead Astray: How the EPA Let One Get Away, WAsh. MonThLY, Oct. 1982, at 40 (examining EPA's enforcement actions against small lead smelter). But see Stone, supra note 5, at 71 (large firms already enjoy benefit of limiting their liability by contracting out risky projects to undercapitalized firms). How much further would the scale of such risk externalization extend if neither owner-managers nor hired managers could be held accountable for negligent decisionmaking? The response to this question, speculative as it must be, is the only possible yardstick by which to measure the protection that dual liability currently offers the public.

39. See supra p. 862 (organizational buffer provides de facto immunity from personal liability).

40. See K. Arrow, Essays in the Theory of Risk-Bearing 140 (1971); Halpern, Trebilcock \& Turnbull, supra note 35 , at $138-45$. 
to detailed investigation elsewhere. ${ }^{41}$ For present purposes, it is enough to consider the implications of the plausible conclusion that existing law allows too much corporate risk externalization. ${ }^{42}$ The relevant question then narrows to a comparison between the merits of expanding the insurable personal liability of top managers or directors, and other, more direct legal responses to undercapitalization, such as mandatory enterprise insurance or minimal capital requirements. ${ }^{43}$ In such a comparison, the dual liability scheme may fare quite well whenever firms can rely on an efficient and complete insurance market. ${ }^{44}$

The chief advantage of expanding the liability of corporate officers or directors is flexibility. First, expanded liability offers flexibility of scope. The managerial duty to supervise that triggers personal liability could be tailored precisely to the classes of corporate torts for which a limitation on liability seems especially inappropriate. We could, for example, impose liability on corporate officials for torts that apparently result from pervasive, firm-wide inattention to safety precautions or risk levels. When pervasive inattention to risk occurs in conjunction with corporate inability to pay full tort damages, it rises to the threshold of deliberate policy. Here, restricting liability to the firm and its lower-level agents does more than subsidize an occasional but inevitable tort loss; it provides an incentive for firm decisionmakers to underprice risk and underinvest in safety. Al-

41. Thus far, most economic analyses of the effects of limited liability and undercapitalization on involuntary tort creditors appear as appendages to broader discussions of their effects on contract creditors. See, e.g., R. PoSNER, Economic ANAlysis of LAw § 14.4 (2d ed. 1977); Halpern, Trebilcock \& Turnbull, supra note 35 , at 145-47. The analytical framework established by these broader discussions is nevertheless useful. Limited liability is a form of "bankruptcy insurance" provided by creditors and must be evaluated in part against the yardstick of how efficiently and completely the insurance market might absorb risks in its absence. See Halpern, Trebilcock \& Turnbull, supra note 35 , at 138-45. In the broader legal literature, Stone provides a powerful brief against the principle of limited corporate liability for tort damages, see Stone, supra note 5, at 65-76, as well as a useful reminder that the problem of undercapitalized firms extends beyond the marginal world of tiny, owner-managed firms, id. at 70-72. The literature still apparently lacks any equally sophisticated analysis of the risk-subsidy benefits of a rule of limited tort liability-if, indeed, these can be demonstrated for an economy equipped with well-developed insurance markets.

42. See R. PoSNER, supra note 41, § 14.4; Halpern, Trebilcock \& Turnbull, supra note 35, at 145-47; Stone, supra note 5, at 65-76.

43. Regulations combining mandatory insurance and financial responsibility tests have been adopted, for example, pursuant to $\$ 3004$ of the Resource Conservation and Recovery Act of 1976, 42 U.S.C. § 6924 (1976 \& Supp. V 1981). See 40 C.F.R. § 264.140-.151 (1982) (establishing insurance requirements or evidence of self-insurance for operators of hazardous waste disposal facilities); Hall, supra note 31, at 615-17 (discussing requirements). A third direct solution to the thin-capitalization problem is, of course, to permit courts implicitly to fix capitalization requirements by disregarding the corporate fiction when they find that firms are undercapitalized. See supra note 32. For a discussion of the difficulties of this approach, including the uncertainty that it might create and the problem of determining a "reasonable" capitalization short of full tort damages, see Clark, supra note 32, at 547-50.

44. The private insurance market may refuse to underwrite some liability risks at all. See Hall, supra note 31, at 617 (liability for Superfund risks so uncertain that private insurance firms reluctant to issue policies); cf. supra note 31 (discussing how pressure of liability risks led to changes in policy coverage). 
though this is not the only "moral hazard" afflicting a regime of limited liability, it is the most serious because it bears most directly on the frequency of accidents. ${ }^{45}$ Moreover, firm-wide inattention to risk and safety surely lies within the province of top management to correct or offset with coverage from assets or insurance.

Second, managerial liability affords firms flexibility of response. Managers can react to expanded personal legal risks in light of the firm's particular circumstances. Unlike requirements for minimum insurance or "adequate" capitalization, managerial liability leaves risk evaluation to the firm's top managers, who are presumably the best acquirers of information about corporate risks, internal firm controls, and existing levels of insurance coverage or capitalization. Thus, it protects against legislative over- or under-provision for tort risks, and it permits managers to select the optimal strategy for covering risk from among insurance, self-insurance, and risk reduction through the control of firm activities. ${ }^{48}$

By contrast, objections to expanding managerial liability center on the hardships that such an expansion could impose on individual managers. Liability based on a broad theory of managerial responsibility conflicts with the normative principle that personal liability be based on personal fault. ${ }^{47}$ It thus resembles anomalous instances in the criminal law where corporate officers are held strictly liable for firm delicts. ${ }^{48}$ Further, it would force managers either to acquire realistic appraisals of potential liability for organizational torts and commensurate levels of insurance, or to face heavy expected liability costs which would fall disproportionately on the wealthy. ${ }^{40}$

45. As I mentioned supra note 32, shareholders can exploit limited liability in two ways: They can diminish assets relative to risk levels or increase risk levels relative to assets. Either strategy increases the volatility of expected returns and hence the value of the shareholders' "option." See supra note 16. Both strategies pose the danger of displacing expected tort damages onto their victims. A reduction of available assets relative to "normal" risk, however, bears only indirectly on the frequency of accidents. Its primary effect is to lead to the production of too much risky activity in the long run: An undercapitalized producer, for example, may undersell competitors and expand production. By contrast, inattention to risk levels generates higher expected accident costs in the short run. See G. CALABresi, supra note 13, at 73-75. Moreover, it is at least possible that the undercapitalized producer takes greater safety precautions but happens to be unlucky. Such mitigating possibilities seem less likely when the evidence points to firm-wide insensitivity to risk.

46. Halpern, Trebilcock, and Turnbull's argument concerning the personal liability of directors of widely held companies similarly depends on the costs of acquiring such information. Halpern, Trebilcock \& Turnbull, supra note 35, at 149-50.

47. Formally, of course, fault exists whenever a duty to supervise is imposed and is breached. When that duty is expanded to the threshold of strict liability, however, it loses its traditional moral overtones.

48. See United States v. Park, 421 U.S. 658, 670-73 (1975) (statute holding head of corporation liable for violation of Food and Drug Act need not depend on conscious wrongdoing of executive).

49. Without adequate capitalization or insurance coverage, the amount of a manager's personal assets would provide the only certain limit on his or her liability for firm torts. Wealthy managers would therefore bear a disproportionate share of the firm's expected damages in the event of bankruptcy. 
These objections carry little weight, however, in a legal world that permits pervasive contractual risk shifting. In such a world, the stigmatic connotations of legal breach have already largely disappeared-at least for garden-variety negligence. ${ }^{50}$ Personal liability, then, is already understood as a neutral incentive, akin to a tax on risk taking, rather than as a "punishment" needing a basis in the principle of individual fault. Moreover, the ease with which corporate managers already arrange to appraise and insure against legal risks suggests that the additional burden created by an expanded duty to supervise would not be large. ${ }^{51}$ Members of professional partnerships manage to tolerate similar risks of personal liability with apparent ease; the ready availability of insurance permits relatively decentralized operation in even the largest of these partnerships without timeconsuming monitoring by each partner. ${ }^{62}$

This nonintrusive property of shiftable personal liability-its ability to serve as an insurance incentive without inducing unwarranted efforts to restrict the riskiness of firm activities-may even make it suitable for extension to outside corporate directors. If the primary effect of a limited supervisory duty on top inside managers is to spark a review of personal insurance coverage rather than a redoubling of supervisory efforts, imposing a similar duty on the corporate board and its outside directors achieves the same result. Such a duty would be fictional, much like the board's existing statutory duty to manage the firm, but, unlike that duty, it would carry a very real risk of personal liability. Precisely this risk of vicarious personal liability would serve as a "pure" insurance incentive. It could not

50. This is not to say that ordinary tort duties never carry moral weight, but only that they do not ordinarily do so in today's business world. The incongruity of permitting legal risk shifting where the law intends to prescribe minimally acceptable norms of behavior is addressed infra note 57 .

51 Appraising personal liability risks will place no burden at all upon the vast majority of publicly held corporations whose assets or insurance coverage already prove adequate. Indeed, one of the great advantages of personal liability as an insurance incentive is the impetus that it gives to employ the underwriting market as a low-cost method of pricing risk. This incentive value is lost when insurance coverage is unavailable, see supra note 44 , or when unpredictably large liability triggers an unanticipated breakdown in insurance coverage-as has recently occurred, for example, in asbestos litigation. See Asbestos Firns Push a Law to Limit Their Liability; But AFL-CIO Is Leery, Wall St. J., Dec. 20, 1982, at 1, col. 6 [hereinafter cited as Asbestos Liability]. It may also be jeopardized by restrictions on policy coverage. See supra note 31 .

52. For an alternative account of the role of personal liability as a "bonding" device in professional partnerships, see Fama \& Jensen, Agency Problems and Residual Claims, 26 J.L. \& EcoN. 327, 336-37 (1983) (arguing that professional partnerships "contract for unlimited liability" to assure customer compensation for losses and bond the quality of partner services); $c f$. Gilson \& Kraakman, supra note 16 (liability under $\S 11$ of Securities Act augments underwriters' reputations as a means of reducing the verification costs of investors). In most states, the law concerning professional service corporations may reduce the risk of personal liability for partnership torts without triggering a wholesale exodus from the partnership form. See DEL. CoDE ANN. tit. 8, $\$ 608$ (1983) (shareholder of professional corporation remains personally liable only for his own wrongful acts and those committed by persons "under his direct supervision and control"); MODEL Business CoRP. Acr: Professional. Corporation Supplement $\$ 11$ comment (1982) (despite lack of explicit language, "it seems that shareholders of professional corporations have limited liability under existing statutes in most states"). 
be mistaken for a duty to intervene in the management of the firm. It would not ask too much from directors, only that they recognize their own liability risks and delegate the task of appraising risk and providing adequate coverage to the insurance markets or reliable consultants. Finally, liability that extends even to outside directors would harness the interests of the one group of "managers" whose risk preferences and stake in the firm are least likely to support a gamble that jeopardizes their personal assets.

Of course, such a flexible approach to the initial placement of liability risks, even on outside directors, is justifiable only when the firm can easily reallocate these risks by low-cost agreement. In large measure, the merits hinge on the structure of the insurance markets and the scope of available policy coverage. By contrast, the crucial characteristic of the two forms of absolute personal liability that I consider next-control liability and gatekeeper liability-is precisely the difficulty of reallocating these forms of legal risk by private agreement.

\section{Control Liability and Sanction InSUfficiency}

Absolute liability involves the largely punitive forms of liability for which risk shifting is either prohibited or simply impossible. Imprisonment creates absolute liability because culpable individuals cannot truly shift this sanction, even if they can be induced to risk it for a price. By contrast, the personal risk of incurring a fine or damages becomes absolute only if it cannot be shifted by indemnification or insurance. Specific legislation or administrative policies may explicitly proscribe shifting the risk. ${ }^{\text {ss }}$ Alternatively, wrongdoing may be absolute because of the general bar against shifting costs of liability for torts or crimes committed in bad faith. ${ }^{\text {"4 }}$ Since the legal consequences of wrongdoing are typically uncertain ex ante, and indemnity or insurance recoveries may not always materialize, many torts and most crimes carry some risk of absolute liability.

The uncertain contours of absolute liability thus raise another essential aspect of the debate over the proper function of dual liability: When should managers be personally liable for firm wrongdoing without recourse to private risk-shifting devices? This question surfaces anew when-

53. See, e.g., Globus v. Law Research Serv, 418 F.2d 1276, 1287-88 (2d Cir. 1969) ( 11 of Securities Act bars indemnification of underwriter who knew of untruth of material statement), cert. denied, 397 U.S. 913 (1970); Foreign Corrupt Practices Act of 1977, § 104(b)(4), 15 U.S.C. § 78dd2(b)(4) (1982) (proscribing direct or indirect reimbursement of fines imposed on individuals for willful violations); Securities Act Release No. 4936, I 46(a), 33 Fed. Reg. 18,617, 18,622-23 (1968) (requiring that prospectus of company that indemnifies officials for violations of Securities Act state that SEC believes such indemnification is "against public policy ... and is, therefore, unenforceable").

54. See supra note 11 (discussing counsel's role in evaluating indemnification requests). 
ever legislatures debate restricting indemnification for specific offenses, and, to a lesser extent, whenever enforcement officials or judges select between corporate and individual defendants, civil and criminal penalties, and fines or imprisonment for corporate delicts. In each instance, the relevant issue is the same: Is deterrence better served-for this offense or on these facts-by a shift from contract and market controls that indirectly affect the compliance incentives of corporate decisionmakers to direct control of those incentives through absolute liability?ss

Certainly, there is a powerful normative argument to support absolute liability whenever a top manager's personal conduct breaches flat legal commands, especially when that breach was intentional. Corporate officers who conspire to fix prices or who bribe the purchasing agents of foreign customers, for example, violate federal criminal statutes. ${ }^{58}$ Such activities lie outside the realm of ordinary tort and are deemed illicit at any price. It hardly makes sense to allow managers to evade their force through indemnification or insurance: Either risk-shifting device would diminish the law's stature and reduce its power to deter. Violations of these criminal statutes create both a specific injury to identifiable third parties, and a more general erosion of an entire system of specific legal rules. Contractual risk shifting of any sort would merely compound this second, more general, harm. ${ }^{\text {s7 }}$

55. See Shad, Who Pays for Executive Sins?, N.Y. Times, Mar. 4, 1984, at F3, col. 1; Shad Asks Shifts on Liability, N.Y. Times, Feb. 24, 1984, at D1, col. 3 (SEC enforcement actions traditionally proceed against offending firm and occasionally against managers as well, but never against managers alone). Of course, proposals to proceed against managers instead of firms may also serve as a device to reduce aggregate penalties if managers are likely to be judgment proof or to risk less in reputational capital. See id. at D4 (proposing proceeding against managers rather than firms in order to reduce reputational losses of targeted firms).

56. See 15 U.S.C. $\$ 1$ (1982) (price fixing); id. § 78dd-1 (bribery of foreign purchasing agents).

57. This reasoning, which treats the violation of specific legal rules as an attack on the status of all legal controls, as well as on the legitimacy of the political processes and norms that underlie them, is most forceful where proscribed activities are traditionally criminal or intuitively highly blameworthy. Stone, supra note 5, at 29-33. For a discussion of the link between criminal sanctions and the "general" harm inflicted by proscribed activities, see Calabresi \& Melamed, Property Rules, Liabilily Rules, and Inalienability: One View of the Cathedral, 85 HARv. L. REv. 1089, 1124-26 (1972) (suggesting role of criminal sanctions in preserving distinct systems of property, liability, and inalienability rights); Klevorick, On the Economic Theory of Crime, 27 Nomos (1984) (forthcoming) (criticizing economic analysis that purports to explain criminalization of harmful activities without reference to fundamental political norms). In addition, the ban on indemnification for knowing or intentional torts and crimes, see supra p. 863-64, may also be based on the general harm that is presumed to result when calculated law-breaking treats expected penalties as "prices." But see infra p. 889 (offering narrower cost-benefit rationale).

Whatever role such considerations of "general harm" and inherent culpability should play in the assignment of absolute managerial liability, however, they ought not to exclude the simultaneous analysis of immediate harm or the public and private costs of enforcement, particularly in the realm of business regulation. Nor does resort to a cost-benefit analysis of liability strategies endorse a "voluntarist" cost-benefit perspective on the part of firms and managers who are subject to legal norms. Indeed, I implicitly adopt what Professor Mashaw refers to as the perspective of a "compliance critic." Mashaw, supra note 1 (compliance critics view corporate obedience to established legal norms as "non-problematic" goal). I suppose that there is frequently too little compliance because many man- 
But this argument does not fit comfortably within an economic framework that considers only two elements: the local, quantifiable costs of offenses and the public and private costs of legal control. ${ }^{58}$ From this narrower perspective, there is no hard and fast line separating "ordinary tort" from intentional tort or criminal violation. Whether they are punitive or compensatory, all forms of liability generate costs and benefits. The benefits are reductions in the level of harmful activities, or, in the case of ordinary tort, at least assurances that they are adequately "priced." The costs are of three sorts: (1) the public and private costs of enforcement, including expenditures on detecting, prosecuting, and punishing offenders; (2) the private costs of compliance that non-offenders bear, such as riskbearing, agency costs, and overdeterrence; ${ }^{.59}$ and (3) the opportunity costs of foregoing otherwise-profitable delicts. ${ }^{60}$

The net benefits of liability rules are largely determined by the magnitude and allocation of risk. Absolute managerial liability is one way to increase the effective sanctions faced by firms and to reduce the frequency of undeterred offenses. The relevant question is: When is it the right way? If managers are more costly risk bearers than firms, why not simply raise enterprise sanctions, or, better yet, increase sanctions on both managers and firms but allow firms to indemnify managers?

\section{A. The Deterrent Effect of Imposing Absolute Liability}

It is helpful to begin analysis of these questions with an inventory of the deterrence advantages provided by absolute liability as they appear from the vantage point of the theory of the firm. To simplify exposition, I restrict discussion to the case in which top managers directly control offenses. Suppose that these managers are Holmesian "bad men" who are motivated entirely by self interest. Such managers will undertake legally risky projects on behalf of the firm only if their personal risk-adjusted returns promise to exceed what they personally will receive from the firm's best legal investment opportunity. If legal and illegal projects offer identical risk-adjusted returns to the firm, managers will clearly choose the legal alternative since it entails no personal cost, while the illegal project creates the risk of personal sanction and attendant damage to their reputations and careers. For managers to select illegal projects, then, they

agers do regard expected penalties as "price" schedules, but that the high cost of legal controls prevents us from raising the price high enough to discourage these managers.

58. See Becker, supra note 2 , at 170-71.

59. These costs ultimately arise from risk aversion, legal ambiguity, and the possibility of mistake by managers or courts.

60. By hypothesis, the harms to third parties of clear criminal offenses always outweigh the benefits that the malefactor reaps. But see Mashaw, supra note 1 (legal "voluntarists" see no moral duty to obey law if corporation's benefit exceeds "disvalue" to society). 
must expect a premium that exceeds their total expected losses and riskbearing costs.

One strength of absolute managerial liability lies in the difficulty of arranging for such a premium. Of course, there is no difficulty if the firm's top managers double as its principal shareholders; in this case, the owner-managers will merely weigh the firm's expected returns on illegal projects against the combined costs of firm and personal sanctions. Matters stand differently, however, with hired managers. Hired managers have made an undiversified investment of their managerial assets in the firm and must charge dearly for their personal risk-bearing services. Beyond this, just as the costs of monitoring and of the agency relationship induce firms to insure or indemnify managers for shiftable liability risks, so too they serve the cause of deterrence by increasing the costs of illicit bargains. First, it is costly to determine the risk of each project and award the correct risk premium to each "deserving" manager. Second, it is difficult to safeguard against managerial cheating, which, quite perversely, now takes the form of engaging in "too much" legal corporate conduct. Individual managers may accept the premium but never engage in the risky conduct or, if the consequences of the illegal gamble unfold badly, they may subsequently reduce their potential penalties by reporting fellow managers or the firm to enforcement officials. ${ }^{61}$

To some extent, the familiar market controls on top managers may ease this problem of illicit contracting, particularly where returns on offenses are large or competitive pressures are intense. The threat of bankruptcy or hostile takeover might outweigh the expected costs of personal sanctions. Alternatively, the firm's standard compensation practices might be so volatile and lucrative that they override not only managerial risk aversion in directing the firm's routine operations but also the personal penalty risks associated with illegal projects. But such occasions are likely to be rare for top managers. ${ }^{62}$ In the usual case, top managers will require something more: an expectation of additional personal returns that derive from the offense itself. The inability of even the most corrupt managers to extract sufficiently high returns will preclude some illegal projects entirely and raise the requisite break-even point for many more. Consider, for example, the plight of successful chief executives who see profitable pricefixing opportunities for their firms. Why should they risk their future income and reputation when they cannot readily take credit for this dubious service to shareholders or claim a salary bonus commensurate with the personal risk? ?s $^{\text {ss }}$

61. See Coffee, supra note 5 , at 387 n.6.

62. See supra note 25 (discussing efficacy of contract and market controls).

63. The contracting problem in this simple example arises from difficulties in negotiating for 
Beyond enlisting this sort of contracting inefficiency to deter illegal conduct, dual liability promises another, equally basic advantage: It provides two distinct pressure points and thus two chances for successful deterrence. Managerial "bad men" will undertake illegal projects only after calculating, however cursorily, the net benefits both for the firm and for themselves. ${ }^{64}$ Leaving aside the difficulties of managers' securing personal risk premiums, the break-even point for an illegal activity is established jointly by both the firm's and the manager's expected penalty costs. Because firms and managers may be affected differently by the same kind of sanction-for example, punitive damages or fines-imposing these penalties on both firms and managers "diversifies" their impact, and lessens the risk that they were set too low for either of their prospective targets. Firms that are insensitive to current levels of enterprise liability for a particular offense may nonetheless desist from offending because the managers who control the firm's behavior have personal assets which are vulnerable to individual-level fines. In addition, dual liability can also diversify across qualitatively different kinds of sanctions. A firm's managers, for example, might be vulnerable to the risk of stigma and prison from criminal conviction even if the firm, as an entity, is not. ${ }^{85}$ In short, a dual liability regime that joins absolute personal liability with enterprise liability offers two sanctioning tools, each providing a different marginal deterrent. Together, they may provide far more effective deterrence than comparable levels of either could alone.

payment of an adequate risk bonus with representatives of the firm-presumably its directors and principle shareholders. Even revealing the grounds for such a bonus would be costly, since it would release information about the proposed offense and thus raise the expected probability of eventual discovery. Beyond this, the actual negotiation of a suitable risk premium raises problems of determining the risks, the worth of managerial risk-bearing services, and the danger of "cheating" by either side, depending on whether the premium is paid before or after the risk is incurred. See Stone, supra note 5, at 52-55; supra pp. 866-69 (discussing risk shifting). Without the negotiation of a risk premium, however, chief executives are likely to profit from offenses only to the extent that their own total compensation is linked to firm performance. Offense opportunities may still be worth exploiting, but only if they are so lucrative that the executives' share of the net returns from the offenses exceeds their total expected liability costs. In other words, their expected share of the gain must outweigh the nondiversifiable risk of a substantial fine or prison sentence and the loss of lucrative future carnings and status. These simple hypotheses might be tested empirically by contrasting the compliance records of firms for which the personal risk-bearing costs of managers are most likely to be offset by expected gains from offense conduct with compliance records of firms for which they are not. The difficulties of negotiating illicit risk premiums should lead to a high incidence of illegal conduct by top officials: (1) where managers are principal or important equity holders; (2) where firms face intense market pressures that threaten to displace incumbent managers; or (3) where managerial compensation varies dramatically with performance-through, say, stock options or volatile bonus awards.

64. Absent final period problems or highly variable incentive schemes, managers ordinarily profit from firm delicts only if the firm also profits. See supra note 25.

65. See Shad, supra note 55. 


\section{B. Limits on the Magnitude of Enterprise Sanctions}

Whatever the additional deterrence advantages that dual liability provides, however, the basic question remains: Why not rely on enterprise liability, alone or in tandem with shiftable managerial liability, instead? In theory, after all, the additional deterrent kicker of absolute liability can also be obtained by imposing more severe penalities on the firm or on the firm's top managers if the firm's assets are insufficient. In practice, however, enterprise liability may fail because of sanction insufficiency. It is often impracticable to raise penalties on a firm to an adequate level. Such "failure" may take two forms. First, effective penalties on firms simply cannot be made arbitrarily severe in the real world; they are limited by absolute constraints, cost considerations, and impediments arising from widespread convictions and institutional practices at every level of the legal system. Second, even if forcing larger penalties on firms alone could reduce residual harm from a particular offense at an acceptable cost, absolute liability imposed on managers may sometimes be less costly.

Consider the simpler form of sanction insufficiency, which arises directly from the practical limits on the severity of firm penalties. ${ }^{68}$ Such limits are particularly significant for the many complex, low-visibility offenses that outsiders can detect only with great difficulty. These offenses run the entire gamut of business delicts, from transactional offenses, such as price-fixing or securities fraud, to key production offenses, including many serious violations of product safety and pollution regulations. ${ }^{67}$ Here, as elsewhere, the effective deterrent will not be the formal sanction as imposed, but rather the formal sanction as discounted by the probability and timing of successful detection and prosecution. For these offenses the discount factor is likely to be particularly large. ${ }^{68}$

In addition, there are significant restrictions on the potential magnitude

66. For more detailed discussion of the limits of enterprise penalties, see Coffee, supra note 5 , at 389-407; Stone, supra note 5, at 24-28.

67. See, e.g., W. Schwartz, Private Enforcement of the Antrtrust Laws: An EcoNOMIC CRITIQUe 2-3 (1981); Coffee, supra note 5, at 391.

68. Thus, any practical limits on either the magnitude of formal sanctions or the likelihood of their imposition will constrain the maximum expected penalties that firms confront. In addition to dual liability strategies-the specific focus of this Article-there are other enforcement devices for circumventing limitations on expected penalties. These range from secondary controls over firm "inputs" that seek to decrease the risk of primary violations (as, for example, speed limits seek to decrease the risks of accidents caused by hazardous driving) to reporting requirements and government inspection. Professor Stone provides a taxonomy of these devices and "interventionist" legal techniques. See Stone, supra note 1, at 5-19; Stone, supra note 5, at 36-45; see also Wittman, Prior Regulation Versus Post Liability: The Choice Between Input and Output Monitoring, $6 \mathrm{~J}$. LEGAL STUD. 193 (1977) (contrasting regulation of inputs with ex post liability for harm). Both interventionist devices and strategies that attempt to compensate for a low probability of successful prosecution serve in large part as techniques for reducing the information costs of legal control. As such, they may warrant systematic comparison with institutions that reduce the cost of information in market settings. See infra p. 900. 
of enterprise sanctions. First, normative limits constrain sanctions. Other values compete with deterrence for the allegiance of the legal system. Retribution, for instance, seeks a measure of equivalency between the injury an actor caused and the punishment meted out, ${ }^{89}$ and equal treatment requires similar penalties for similarly harmful offenses..$^{70}$ Both norms rest on ex post evaluations of the harmfulness of offenses; both support a relationship of rough proportionality between the harm of the offense and the severity of sanctions. Thus, both norms indicate that punishing less harmful but easily hidden delicts more severely than serious but obvious offenses would distort the structure of penalties. ${ }^{71}$ For this reason, these norms may resist efforts to raise formal penalties to offset the likelihood that many offenses are never successfully prosecuted.

Second, an appealing if not always properly circumscribed economic consideration weighs heavily against penalizing firms into bankruptcy. In the absence of perfect markets, the punitive liquidation or reorganization of culpable firms may hurt not only managers and shareholders, who arguably deserve punishment, but also all other participants within the firm-employees, suppliers, and distributors-who also share in the firm's successes and failures. ${ }^{72}$ For example, if a large fine precipitates the shutdown of a marginally profitable firm, employees will face immediate unemployment and perhaps a permanent loss of earnings if they are forced to work in lower-paying jobs. These losses are severe; employees, like managers and many small suppliers, cannot diversify their stake in the firm, and prior to the legal debacle they are unlikely to have received any wage premium fully reflecting the risky character of their "investment." "3 By contrast, shareholders, who presumably are diversified, may lose little in a shutdown, especially if the firm's earnings prospects are truly marginal. The spectre of this scenario, or something quite like it, is undoubtedly a powerful constraint on enterprise-level penalties, ${ }^{74}$ even

69. See Gross, Punishment, in PHILosophy of LAw 500-02 (J. Feinberg \& H. Gross eds. 1975); Corporate Crime, supra note 3, at 1231-33.

70. See Coker v. Georgia, 433 U.S. 584, 598-99 (1977).

71. For a recent exposition of the principle of proportionality in American criminal law, see Solem v. Helm, $103 \mathrm{~S}$. Ct. 3001 (1983). In addition to competing normative conceptions of "just" punishment, penalty levels may serve functions unrelated to deterrence or retribution. They may, for example, convey a rank ordering of community values about the relative "badness" of offenses. In this case, punishing a minor but hard-to-detect offense more harshly than a heinous offense would convey the wrong signal. For discussion of the tensions between efficiency and competing norms in other allocational decisions, see G. Calabresi \& P. Bobbitt, Tragic Choices (1978).

72. In the case of reorganization, of course, employees, suppliers, and customers will suffer only to the extent that the firm is forced to curtail its ongoing operations.

73. See Coffee, supra note 5, at 401, 406-07; supra pp. 864-66 (discussing differential capacities to diversify risk).

74. See Roginsky v. Richardson-Merrill, Inc., 378 F.2d 832, 841 (2d Cir. 1967) (denying award of punitive damages against negligent drug company because amount could be "catastrophic"). Consider also reports of the Environmental Protection Agency's reluctance to seek the enormous penalties 
when liquidation is improbable for healthy firms and likely for failing ones regardless of sanctioning. ${ }^{75}$

Finally, as the magnitude of potential fines rises, the marginal benefits of sanctions decrease and the marginal costs increase. Marginal benefits decline because few additional culprits are deterred past a certain point. ${ }^{\text {pe }}$ Marginal costs for both enforcers and innocent firms will rise. Individual sanctioning errors will become more costly as mistakenly convicted firms receive larger penalities, and the expense of successful prosecution is likely to rise as firms invest more in defensive tactics, and as judges and juries become more reluctant to convict. ${ }^{77}$ Similarly, the costs of overdeterring innocent, risk-averse managers-the costs of self-monitoring and the fore-

for continuing violations of air pollution standards authorized by the Clean Air Act of 1970, 42 U.S.C. $\$ 7413$ (1976). See Madlin, supra note 38; Good Hope, La., Refinery Leads State in Fines for Violating Pollution Laws, Wall. St. J., Sept. 21, 1982, at 20, col. 1 lhereinafter cited as Good Hope Refinery]. Some small polluters with limited assets are apparently not only aware of this reluctance, but have learned to exploit it. Madlin describes a case in which a small firm emitting dangerous levels of lead pollution succeeded in evading detection for nine years through the simple expedient of failing to apply for an emissions permit, and, after its chance detection, continued to pollute under the threat of a $\$ 25,000$ per day fine until reaching a negotiated settlement costing a tiny fraction of its maximum possible fine of $\$ 25,000,000$. Madlin, supra note 38, at 44; see also Good Hope Refinery, supra (EPA accepts fraction of assessed fines after oil refinery pleads poverty; deterrent effects of fines questioned). Ironically, recent products liability litigation suggests that private lawsuits seeking ordinary tort damages are more likely to force bankruptcy than the deterrent efforts of enforcement officials. See Asbeslos Liability, supra note 51 (Manville Corp.'s bankruptcy precipitated by potential liability for asbestos-related injuries).

75. This reluctance rests on a financial paradox. Fines are one-time financial costs and are wholly independent of the expected returns on the firm's legal projects. Thus, although enterprise sanctions may trigger bankruptcy, they will have little effect on the decision to liquidate firm assets. They may hasten the dismantling of already moribund firms, or force new ownership and management on profitable ones, but in the absence of serious capital market imperfections, they should not eliminate any but the most marginal enterprises and projects. But see Coffee, supra note 5, at $401 \mathrm{n} .50$ (large fines may induce even solvent firms to cut back, particularly since access to capital markets is likely to be impaired).

Whatever the actual state of affairs, however, the spectre of forced liquidation and its attendant costs for innocent firm participants will continue to inhibit the imposition of very costly sanctions on firms. The popular equation of bankruptcy with liquidation, and of large fines with operational cutbacks, is deeply rooted. For some sophisticated observers, moreover, the costs of extinguishing even marginal firms or business projects may appear too great. Id. An apparent equivalent of a large monetary fine-a forced issue of equity securities-might surmount transactional difficulties imputed to monetary fines. See id. at 413-24 (proposing "equity fines"). Were it to do so, it would extend the reach and cost advantages of enterprise liability.

76. If sanctions are already severe, then it is easy to see how the marginal benefits of increases in the severity of penalties will decrease. Much depends, however, on the distributions of returns and the harms associated with particular kinds of offenses. When, for example, important economies of scale attend offense activities, that is, when large and lucrative offenses are the norm, marginal enforcement benefits may actually increase with progressively higher penalty levels because small penalties have virtually no deterrent impact.

77. See Coffee, supra note 5, at 405-07. The expected increase in the marginal costs of these prosecution-related activities is plausible but not axiomatic. Increased costs associated with individual prosecutions may be offset by a decline in the number of offenses, and hence the number of prosecutions required to maintain a given probability of punishment. See Becker, supra note 2, at 185-90. 
gone profits when managers avoid legally ambiguous behavior-will increase. ${ }^{78}$

Up to a point, of course, increasing the probability of detection and prosecution can raise the expected costs of punishment without inflating the size of penalties that are actually imposed. But the sheer cost of detecting low-visibility, complex business offenses counsels against expecting too much from this stratagem. Too often, detection depends largely on reports from victims or on insider betrayal. The rate of informational "leakage" about offenses from these sources is likely to fix an invariant maximum probability of detection-and therefore prosecution-at any cost.

Contracting out the detection function by encouraging punitive civil damage actions might economize on information costs, but such economy in public enforcement is achieved only with concomitant expenditures on private litigation and with the moral hazards and enforcement difficulties that these create. ${ }^{79}$ Moreover, victims and business competitors are still outsiders. Since they are already motivated to report offenses, the marginal gains from private bounty-hunting are likely to be limited. Increased public investment in prosecution is also problematic. The diminishing marginal returns of increased prosecutorial effort and the invisibility of social gains from deterring offenses conspire to make enforcement expenditures peculiarly vulnerable to budget-cutting, especially when the harm itself is of an undramatic, barely-visible sort.

78. Overdeterrence of non-offenses occurs when legal rules are overinclusive, or when their ambiguity or complexity causes mistakes. Overdeterrence is most common in areas such as antitrust, where beneficial conduct may frequently appear risky or even technically illegal. See W. SchwarTz, supra note 67, at 22-25; Block \& Sidak, The Cost of Antitrust Deterrence: Why Not Hang a Price Fixer Now and Then?, 68 Geo. L.J. 1131, 1133-38 (1980); see also supra p. 867 (antitrust example). If non-offenders who engage in beneficial but legally risky activities are risk averse, increasing penalties will generate increased marginal overdeterrence costs. See Polinsky \& Shavell, The Optimal Tradeoff Between the Probability and Magnitude of Fines, 69 AM. Econ. Rev. 880, 884 (1979). Most top managers are likely to be risk averse in establishing the firm's policies even without absolute liability, and are much more likely to be so with it. See supra pp. 867-68.

79. The peculiar costs of the private market for enforcers arise from several sources. One is the potential for aggregate over-investment in enforcement, which arises because punitive fines (say, treble damages) are set to deter offenders, but not to "price" offenses for purposes of allocating enforcement resources. See Landes \& Posner, The Private Enforcement of Law, 4 J. Legal Stud. 1, 10-16 (1975). A related cost of private enforcement is the risk of bad faith or misdirected private actions induced by the lure of large potential recoveries. See K. Elzinga \& W. Brert, THE ANTITrust PENalties: A Study in LAw AND Economics 81-96 (1976). Finally, public or monopolistic enforcement may offer economies of scale in the detection and prosecution of offenses, which competitive enforcement cannot replicate. See Landes \& Posner, supra, at 29-30; Polinsky, Private Versus Public Enforcement of Fines, 9 J. Legal Stud. 105, 107 (1980). 


\section{Rationales for Absolute Liability}

This brief inventory of constraints on enterprise penalties completes the limited case for supplementing penalties on firms by using absolute managerial liability. First, regardless of the comparative costs and benefits of the two kinds of liability, managerial liability can circumvent absolute limits on enterprise sanctions. Imposing modest sanctions on culpable managers, who might otherwise escape punishment, avoids concerns over the ex post fairness of imposing disproportionately severe sanctions on firms for modest offenses. And where the firm is nearly judgment proof, managers who control the firm's activities can still serve as targets for fines or more potent criminal penalties. ${ }^{80}$ Second, absolute managerial liability promises to do more than merely circumvent limitations on enterprise penalities; it also permits the advantages of "sanction diversification" and the ability to exploit intra-firm conflicts of interest in the service of deterrence and enforcement. ${ }^{81}$

The limited rationale for managerial liability assumes, however, that we have exhausted the opportunities for increasing enterprise liability and that the gravity of undeterred offense behavior still warrants additional sanctions. Yet, even if it were possible to increase penalties on firms, enterprise liability might still "fail," albeit relatively, because the total costs of increasing enterprise sanctions needed to achieve a targeted reduction in offenses are greater than those of a mixture of enterprise liability and absolute liability on controlling managers. Since personal liability ordinarily inflicts greater compliance costs on innocent firms by increasing managerial risk bearing, ${ }^{82}$ it must possess other advantages that can offset this disadvantage if it is to compare favorably with heavier enterprise sanc-

80. This observation suggests an obvious point: The distribution of bankruptcy points over offending firms may have a significant impact on the selection of a dual liability standard. Where entry barriers are low and an industry contains chiefly small firms with limited assets, we would expect greater reliance on absolute personal liability.

81. See supra pp. 881-82.

82. Of course, personal liability yields a compliance benefit to firms in those exceptional circumstances where managers might otherwise assume "too much" legal risk on the firm's behalf. See supra note 25 (managers may occasionally assume too much risk for reasons of personal taste or as a means of enhancing compensation). All firms presumably bear some risk of such a breakdown in internal controls. Given the fundamental managerial bias toward too little-rather than too much-risk taking, however, this compliance benefit to the firm is unlikely to outweigh the compliance costs of managerial risk bearing, at least for top-level managers and for misconduct that benefits the firm in the first instance.

Absolute personal liability may reduce firm compliance costs, however, for a variety of offenses outside the scope of this Article. Offenses such as insider trading, which benefit managers directly rather than through the firm, place considerable pressure on private controls over managerial behavior. Enterprise liability would be warranted only if firms could identify and punish offenders more efficiently than outside enforcers could-an unlikely circumstance in the case of insider trading. See Gilson \& Kraakman, supra note 16 (discussing economies of scale in policing insider trading); $c f$. Kornhauser, supra note 5, at 1370-72 (imposing liability on agents may induce greater care if courts are better monitors than firms or if there are constraints on permissible employment contracts). 
tions. Given the assumption that managerial and enterprise liability can achieve the same net reduction in offenses, these other advantages can only arise from economies in enforcement costs-the costs of detecting, prosecuting, and punishing offenses.

\section{Costs of Enforcement}

Surveying offenses from the perspective of an enforcement agency with a limited budget, it is easy to see how absolute managerial liability becomes increasingly attractive at progressively higher levels of enterprise sanctioning. As higher firm penalties successfully deter larger proportions of vulnerable firms from illegal conduct-and as limits on absolute penalties or other factors immunize additional potential offenders from greater firm-level penalties-enterprise liability becomes more costly and less effective. The costs of increases in firm penalties or of detection and prosecution needed to dissuade an appreciable number of the remaining wouldbe offenders become progressively greater. By contrast, because managerial liability threatens a new population of potential offenders-individual managers-it should deter cheaply, even at modest levels of severity. In addition, since the same resources already expended for detection and prosecution of offending firms also generally suffice against their managers, enforcement officials can purchase deterrence at little additional cost.

Absolute managerial liability also reduces enforcement costs in other ways. For example, the judicious use of modest sanctions against both firms and managers reduces the risk of forced liquidation of small or marginal firms and the attendant cost of an "overspill"Bs of punishment onto innocent parties. Alternatively, managerial liability might reduce detection and prosecution costs by providing enforcement officials with a bargaining chip to trade for information about easily hidden offenses. Although top managers may not often volunteer information about undetected wrongdoing, matters stand differently once an investigation has begun. ${ }^{84}$ Under a regime of dual liability, as the investigation proceeds, the expected costs of personal sanctions increase, the likely benefits of continued loyalty to the firm decline, and the attraction of trading information for lenient treatment rises accordingly. There is, in short, a symmetry here with the pre-offense deterrent advantages of managerial liability: Just as contracting difficulties can make hired managers hesitate before committing an offense, they can encourage hired managers to aid in the detection and prosecution of an offense after its commission.

83. See Coffee, supra note 5 , at 405 .

84. See id. at 387 n.6 (discussing dynamics of plea bargaining with culpable managers). 


\section{Costs of Compliance}

Standing alone, however, savings on enforcement costs are not enough to recommend absolute managerial liability. We must also consider the costs of compliance that such liability imposes on regulated firms: the cost of compensating managerial risk bearing, the agency costs incurred because of managerial overdeterrence, and the overcommitment of firm resources to risk avoidance. The choice between managerial sanctions and enhanced enterprise liability must accordingly hinge on the total costs of legal control. These will differ with the relative contributions of enforcement and compliance costs. Since the mix will vary for different offenses, selecting the liability strategy for a particular offense requires detailed investigation. I have already noted the most important enforcement cost considerations; the relevant compliance cost considerations are even simpler. These costs arise from managerial risk aversion and the ever-present possibility of legal mistake or miscalculation. ${ }^{85}$ Absolute liability thus seems best suited to violations of clear-cut legal rules with little prospect of error in adjudication or to violations of underinclusive rules for which even the penumbra of risky innocent conduct is of dubious social value, since neither category is likely to generate costly legal mistakes. Indeed, wherever the costs of overdeterrence are not important to the overall calculus of liability costs, the sensible strategy may be to permit enforcement officials and judges to determine the actual assignment of liability between firms and managers on a case-by-case basis. ${ }^{86}$ But even with this delegation, the discretion to employ a mix of policy tools, each with its own marginal costs and benefits, is likely to be cheaper than relying on any one tool alone.

Stepping back from the narrow economic arguments that favor absolute managerial liability, however, it is clear that not all undeterred wrongdoing demonstrates either sanction insufficiency or the need for absolute managerial liability. Some degree of underdeterrence is the normal lot of prescriptive liability rules. But absolute liability is strong medicine; ideally, it should be taken only after weighing its costs against the alternative of increasing sanctions on the firm alone. Viewed from this perspective, the general rule permitting indemnification absent bad faith or reasonable cause to believe that conduct is criminal may function as a serviceable proxy for more refined calculation. ${ }^{87}$ The rule is formulated this way not

85. See supra pp. 867-68.

86. The danger that accurate information about legal risks may be impossible to obtain is a crucial difficulty with delegating to individual enforcement officials the discretion to allocate liability between managers and firms. For an inventory of the advantages of the "market system of prosecution," see Easterbrook, supra note 2, at 292-98.

87. Generous latitude to indemnify is similar in this respect to the rigorous proof and culpability 
because ignorant managers are helpless to prevent firm delicts-liability provides an incentive to become informed-but because it radically circumscribes the risk of liability triggered by personal legal mistake. Such a rule minimizes the risk-bearing and agency costs of innocent firms because it assures that their managers will rarely blunder into absolute penalties without prior notice. Of course, we might still choose to impose absolute liability for serious regulatory offenses-for example, gross violations of laws governing the use and disposal of hazardous chemicals ${ }^{88}$-or for breach of the duty to report material information concerning a new issue of securities. ${ }^{89}$ But this decision should rest upon an explicit determination of the savings in cost that warrant absolute liability for particular classes of offenses.

Finally, if not every offense requires the remedy of absolute liability, the converse is equally true: Absolute liability cannot provide the whole cure for every corporate delict. The Wall Street Journal reports almost daily on at least one controlling executive from a substantial firm who (now to his regret) chose to gamble personal liability against the returns on bribery, price-fixing, or third-party fraud. ${ }^{90}$ These executives may be aberrant risk lovers, or they may simply chance upon particularly lucrative, illegal opportunities. But whatever the circumstances, one thing seems clear: They do not gamble their careers and personal freedom expecting to be caught. Beyond a certain point, no amount of tinkering with sanctions can further deter profitable but nearly invisible offenses. If the offenses are still too frequent, the problem lies less with inadequate sanctions than with prohibitive costs of detection. This failure can be characterized as enforcement insufficiency. The attendant remedial genre of dual liability is gatekeeper liability, which attempts to force a portion of the enforcement burden onto firm participants who are not themselves the initiators of corporate delicts.

\section{GATEKEEPER LIABILITY AND ENFORCEMENT INSUFFICIENCY}

Enforcement insufficiency occurs when both enterprise and individual penalties fail to elicit sufficient compliance at an acceptable cost. The dis-

standards that circumscribe most criminal penalties. Just as the general indemnification rule permits risk shifting in deference to the costs of managerial risk bearing for all but a very few offenses, so a default culpability threshold of criminal intent or knowledge restricts severe criminal sanctions to those delicts least likely to give rise to legal error. See R. POSNER, supra note $41, \S 7-4$.

88. See, e.g., Federal Water Pollution Control Act of 1972, 33 U.S.C. § 1319(c)(2) (1976); Resource Conservation and Recovery Act of 1976, 42 U.S.C. $\$$ 6828(d)(3) (Supp. V 1981).

89. See supra note 53 (Securities Act policy against indemnification).

90. See, e.g., Frigitemp Ex-Chief Admits Conspiring to Bribe Former General Dynamics Aides, Wall St. J., Dec. 8, 1983, at 7, col. 1; Was It Bribing When Donald Crawford Sent Money to 'the Folks'?, Wall St. J., Feb. 23, 1983, at 1, col. 6. 
tinction between enforcement insufficiency and sanction insufficiency is one of degree: Insufficient enterprise sanctions still leave open the possibility of sidestepping constraints on penalties by punishing managers; enforcement insufficiency results only after this alternative has also been exhausted.

Like sanction insufficiency, moreover, enforcement insufficiency is a relative concept. Just as sanctions are "insufficient" only if absolute managerial liability can provide cost-effective deterrence, so enforcement insufficiency exists only when there is a cost-effective enforcement alternative. Because our inquiry focuses on liability rules that operate on a firm's top participants, only one alternative remains: the possibility that civil or criminal liability can induce firm participants outside the circle of controlling managers to discover and prevent offenses. These outsiders are potential gatekeepers. The scope of their liability as gatekeepers depends on the reach of their duties to monitor for and respond to corporate wrongdoing.

General civil and criminal rules of secondary liability such as the aiding-and-abetting and conspiracy doctrines ${ }^{91}$ impose a limited form of gatekeeper liability on all firm participants. Yet without the gloss of an explicitly specified duty, these doctrines are default provisions, much like the general rules governing the indemnification of managers. They do not require any affirmative action, but only a passive refusal to facilitate a known ongoing offense. ${ }^{92}$ By contrast, true gatekeeper liability joins the risk of absolute liability with an active duty to monitor for offenses. It imposes liability on an entirely new class of innocent gatekeepers (in addition to controlling managers) to reduce enforcement costs, the frequency of offenses, or both.

Top managers themselves are also targets of an enforcement strategy akin to gatekeeper liability when they face absolute liability for delicts initiated by others. Absolute liability triggered by broad supervisory duties falls into this category, as does the startling prospect raised by United States v. Park $^{\mathbf{9 3}}$ of imposing strict criminal liability on a large firm's chief executive for corporate delicts-in Park, for unsanitary conditions in distant warehouses. ${ }^{94}$ But the paucity of such examples suggests how they differ from true gatekeeper liability. Controlling managers already serve

91. For critical discussion of the incorporation of these doctrines into securities law, see Fischel, Secondary Liability Under Section 10(b) of the Securities Act of 1934, 69 CALIF. L. Rev. 80, 83-86 (1981).

92. See W. Prosser, Handbook of The Law of Torts 291-93 (4th ed. 1971) (discussing requisites for vicarious liability for torts arising from concerted action). But see Fischel, supra note 91 , at 81-88 (describing expanded scope of doctrines in securities law).

93. 421 U.S. 658 (1975).

94. Stone reviews the brief list of federal statutes that impose specific monitoring obligations on supervisors or managers as well as the legislative history of unsuccessful attempts to expand this duty. See Stone, supra note 5, at 31-33. 
as the firm's chief internal monitors of compliance under a regime of simple enterprise liability. Elevating their supervisory function to a legal duty enforced by personal liability would be useful only if enterprise liability alone failed to induce adequate supervision. ${ }^{95}$ If so, however, the question of when to impose such an expanded duty on managers would merely be a special case of the broader question of when to impose absolute liability on managers at all. By contrast, true gatekeeper liability is designed to enlist the support of outside participants in the firm when controlling managers commit offenses, that is, when the firm's internal monitors have failed.

The first requisite for gatekeeper liability is, of course, an outsider who can influence controlling managers to forgo offenses. For this reason, gatekeeper liability has received widest play in response to securities violations and similar "transactional" delicts rather than in response to wrongdoing that occurs wholly within the bowels of the firm. Gatekeepers can be drafted from among the many outsiders who supply specialized expertise to the managers of publicly-held corporations and facilitate their relations with constituencies outside the firm: outside directors, lawyers, accountants, and investment bankers. ${ }^{96}$ In fact, most of these influential outsiders have already been tapped for limited enforcement duty. Section 11 of the Securities Act of $1933,{ }^{87}$ for example, imposes a duty on directors, underwriters, and accountants to investigate securities registration statements. Similarly, enforcement actions brought under the federal securities laws during the 1970's have expanded the potential liability of lawyers and accountants who have facilitated-or even failed to halt-clients' delicts. ${ }^{88}$ In a parallel development, the accounting standards provisions of the Foreign Corrupt Practices Act of $1977^{98}$ require firms to institute reliable internal accounting controls and proscribe misleading statements by both officers and directors to the firm's accountants, without regard to scienter. ${ }^{100}$

95. See Corporate Crime, supra note 3, at 1270-75 (discussing imposition of criminal liability for "reckless" and "negligent" supervision).

96. See United States v. Benjamin, 328 F.2d 854, 863 (2d Cir. 1964) (Friendly, J.) ("In our complex society the accountant's certificate and the lawyer's opinion can be instruments for inflicting pecuniary loss more potent than the chisel or the crowbar.").

97. Ch. 38, $\S 11,48$ Stat. 74,82 (codified as amended at 15 U.S.C. $\$ 77 \mathrm{k}(1982)$ ).

98. These actions have proceeded both in the courts-as prosecutions for aiding and abetting violations of the antifraud provisions of the securities acts-and in administrative disciplinary proceedings brought by the SEC under its authority to discipline professionals who practice before it. See, e.g., SEC v. National Student Mktg. Corp., 457 F. Supp. 682 (D.D.C. 1978) (setting forth duty to intervene in illegal transaction); In re Carter, [1981 Transfer Binder] FED. SEC. L. REP. (CCH) I 82,847 (SEC Admin. Proc. File No. 3-5464) (duty to take "prompt action" in response to ongoing client offense); $c$. Fischel, supra note 91 , at 82 (discussing recent imposition of liability for securities violations on a range of secondary actors).

99. Codified at 15 U.S.C. $\$ \S 78 \mathrm{dd}-1,78 \mathrm{ff}(1982)$.

100. See Rule 13b2-2, 17 C.F.R. § 240.13b2-2 (1983). 
Despite their disparate roles, moreover, it is easy to see why outside directors, accountants, lawyers, and underwriters are likely targets for a gatekeeper liability strategy. Each has or might have low-cost access to information about firm delicts. Contractually or informally, each already performs a private monitoring service on behalf of the capital markets. ${ }^{101}$ But most important, each is an outsider with a career and assets beyond the firm. At the very least, these potential gatekeepers face incentives that differ systematically from those of inside managers; in the usual case, they are likely to have less to gain and more to lose from firm delicts than inside managers. Indeed, gatekeeper liability can jeopardize not only the personal interests of individual lawyers and accountants, but also the larger interests and reputations of their respective firms or even of their entire professions. ${ }^{102}$

This extensive reach of gatekeeper liability, in particular, suggests that it generally acts to magnify both the costs of compliance for innocent parties and the benefits of effective deterrence for guilty ones in comparison with liability imposed on controlling managers. Outsiders will be more reluctant than managers to risk personal liability on the firm's behalf. Thus, if these gatekeepers can detect offenses, it will be difficult-or at least very costly-to entice them into a conspiracy. Many offenses will fail because these outsiders prove impossible to corrupt, others will fail because the price of corruption exceeds its potential benefits, and still others will never be attempted in the expectation that they would fail for either reason. But regardless of the mechanism interdicting offenses, whenever potential offenders must employ incorruptible outsiders to gain legitimacy or expertise or to meet a legal requirement, ${ }^{103}$ gatekeeper liability will thwart a class of offenses that are unreachable through enterprise-level or managerial sanctions. Of course, firms will also pay for the risk of addi-

101. See, e.g., Fama \& Jensen, Separation of Ownership From Control, 26 J.L. \& EcoN. 301, 314-15 (1983) (outside directors); Gilson \& Kraakman, supra note 16 (accountants and underwriters); Gilson \& Mnookin, supra note 20 (law firms); Watts \& Zimmerman, Agency Problems, Auditing, and the Theory of the Firm: Some Evidence, 26 J.L. \& EcoN. 613 (1983) (accountants).

102. To the extent that not only individual firms but also entire professions possess reputations that enhance the value of their members' services, the breach of well-understood gatekeeper conventions diminishes the value of a profession-wide asset. $C$ f. infra p. 895 (firm reputation). In a similar way, legal liability and codes of professional ethics may bolster the value of professional services in the eyes of parties who transact with clients by increasing the perceived reliability of individual lawyers or firms who lack established reputations. See Gilson \& Kraakman, supra note 16. SEC enforcement actions during the 1970's sparked a sharp and continuing debate over lawyers' ethical obligations to third parties and public enforcement agencies. See Lorne, The Corporate and Securities Adviser, the Public Interest, and Professional Ethics, 76 Mich. L. Rev. 423, 445-65 (1978).

103. The SEC requires that an independent public accountant certify financial statements in annual reports, registration statements, and other filings governed by its integrated financial reporting rules. See Regulation S-X, 17 C.F.R. $\S 210$ (1983). In particular, Rule 2-01(b) specifies that certified public accountants must be independent "in fact" to be recognized as such by the SEC and lists potential conflicts of interest that bear on independence. Id. $\S 210.2-01(b)$. 
tional liability in the familiar ways. If outside gatekeepers cannot shift their liability risks, they will charge high risk premiums. In addition, they will have a powerful incentive to lobby for the overinvestment of firm resources in monitoring for offenses and against profitable but risky innocent conduct. In the extreme, they may even withdraw their services entirely from small or risky firms.

There is, however, much more to the economic analysis of gatekeeper liability than is revealed by this rough portrait of costs and benefits. Gatekeeper liability is qualitatively more interventionist and therefore more complex than the simple imposition of absolute liability on controlling managers. Its enforcement potential depends not only on the offense and the level of culpability that triggers personal liability, but also on the choice of gatekeepers and upon the design of their duties. Two problems deserve particular mention. ${ }^{104}$

\section{A. The Market for Gatekeepers' Services}

The first of these concerns is the sensitivity of potential gatekeepers to the risk of personal liability. While outsiders will tend to be more vulnerable to legal risk than insiders, the problem of gatekeeper incentives is actually far more tangled than this generalization implies. Corporate managers, for example, are usually free to control the selection and tenure of outside directors, lawyers, and accountants. ${ }^{105}$ Thus, it may be child's play for would-be offenders to select corrupt or captive outsiders who are only too willing to assume personal liability for a price. To evaluate this prospect, we must know a good deal more about managerial incentives in selecting outside participants: What are the incentives to employ reputable law firms and truly independent outside directors, and what are the costs of discharging them?

Similarly, we need to learn more about the specific structure of incentives on the gatekeepers' side of the market. What, for example, are the incentives of individual lawyers and accountants as distinct from the law and accounting firms of which they are members? Although facilitating clients' offenses may be anathema to established firms with deep pockets and venerable reputations, individual members of these firms may face a

104. Considerations of space and complexity preclude a full review of these questions in this Article. I plan to address them at greater length in a future article devoted to gatekeeper liability.

105. Firms registered under the Securities Exchange Act must, however, disclose the discharge or replacement of their principal independent accountant and describe any disagreement over accounting procedures that preceded the change. Form 8-K, Item 4, 42 Fed. Reg. 4429, 4430 (1977). Similarly, issuers of securities must disclose resignations of directors over policy matters and, if the director requests, summarize the director's description of the disagreement. Id. (Item 6). These are, however, extremely modest limits on the power of top managers to control the tenure of accountants and outside directors. 
substantially different set of incentives, especially if derelict clients can aid professional careers, either inside or outside law and accounting firms. ${ }^{108}$ When members of established professional firms facilitate clients' offenses, they effectively expropriate and injure the firm's reputation. This element of "firm-specific capital"107 is among the firm's most valuable assets; it is uninsurable and, unlike the business of particular clients, it cannot be protected by diversifying the firm's clientele. ${ }^{108}$ Thus, the conflict of interest between the firm and its individual members turns the familiar problem of dual liability topsy-turvy. The question now becomes whether to extend liability from the individual to the firm even though the firm may be the more costly risk bearer and may also bear de facto legal risk from a loss of reputation even without formal liability.

\section{B. Gatekeepers' Duties}

Detailed analysis of the incentives on each side of the market for gatekeepers' services, however, is only one factor in predicting the potential efficacy of gatekeeper liability and the proper targeting of these liability rules. Another equally tangled problem is the cost-effective design of the potential gatekeepers' legal duties.

The success of gatekeeper liability hinges on the development of legal duties that encourage the detection and interdiction of offenses without overburdening the private relationships that serve as their vehicles. This requires the prudent crafting of circumscribed duties to monitor and to respond that, above all, do not ask too much from their targets. ${ }^{109}$ The design of duties is further complicated because potential gatekeepers from outside the firm can rarely perform both the monitoring and interdiction aspects of the enforcement function with equal facility. Thus, at least for complex offenses, gatekeeper strategies must ultimately focus on how en-

106. Cf. Gilson \& Mnookin, supra note 20 (examining relation between structure of law firms and nature of client loyalty to individual partners).

107. See id. (describing law firm's reputation as firm-specific capital which attracts clients and permits firm to serve as reputational intermediary on behalf of clients).

108. The conventional distinction between "insiders" and "outsiders" might better be understood as a continuum-even a multi-dimensional continuum-for purposes of analyzing gatekeeper incentives. On the organizational level, for example, an outside law firm is truly "outside" only to the extent that it has a diversified portfolio of clients. Few firms are therefore total outsiders. On the individual level, particular outside lawyers have multiple allegiances-to clients, to their firm, and to the profession-that interact in complex patterns. The senior partner, with an established clientele and professional reputation in his or her own right, will face one set of incentives; the junior partner and beginning associate will face quite different incentives to remain more or less independent of a strong-willed client's interests. For an unusual account of the reactions of five lawyers-each with different professional and organizational interests-to an ongoing corporate securities fraud, see In re Carter, [1981 Transfer Binder] FEd. SEC. L. REP. (CCH) I] 82,847 (SEC Admin. Proc. File No. 35464).

109. Cf. Stone, supra note 5 , at $36-45$ (discussing complexities of crafting bureaucratic standards). 
forcement might be exercised by an interacting network of gatekeepers. Once we fit the scope of liability to the enforcement function for individual gatekeepers, we already forgo any recourse to a fixed relationship between the nature of particular conduct and the sanctions imposed. The next step is fitting the duties and risks of individual gatekeepers to one another to create a secondary control system on the foundations of private contract. $^{110}$

For a simple illustration of such a system, consider the roles of outside counsel and board members. Lawyers may be able monitors of most offenses that are likely to surface in the course of legal research and advising, but they are poorly equipped to veto any but a narrow range of illegal transactions that depend on their direct facilitation-for example, the closing of an illegal merger or fraudulent agreement that specifically requires an attorney's legal opinion. ${ }^{111}$ By contrast, outside directors may be well positioned to interdict a broad spectrum of offenses, but they are singularly ill equipped to detect offenses in the first instance without expert assistance. ${ }^{112}$ Each of these natural weaknesses in enforcement capability must be considered in the design of gatekeepers' duties. One might, for example, impose a response duty on lawyers to report firm delicts to the board; ${ }^{113}$ this could exploit the gatekeeping strengths of lawyers and directors in tandem. Similarly, directors might be given the simplified monitoring duty of ensuring that the firm employs reputable outside counsel and of relying on counsel's advice. ${ }^{114}$

Regardless of the structure of gatekeeping duties, however, the discomfiting fact remains that they depend upon private contractual relationships and business conventions that are themselves subject to continuing evolu-

110. Consider in this regard the analogy to monitoring economies that creditors and other outside interests might achieve by keying contract rights to access to information and to expertise. See Levmore, supra note 33, at 68-75.

111. See Sommer, The Emerging Responsibilities of the Securities Lawyer, [1973-1974 Transfer Binder] FED. SEC. L. REP. (CCH) IT 79,631.

112. See Brudney, The Independent Director-Heavenly City or Potemkin Village?, 95 Harv. L. REv. 597, 632-39 (1982).

113. See Model. Rules of Professional Conduct Rule 1.13 (1983); In re Carter, [1981 Transfer Binder] Fed. SEc. L. Rep. (CCH) II 82,847 (SEG Admin. Proc. File No. 3-5464).

114. The judicially evolved "reliance-on-counsel" defense serves a related function. It permits corporate officers and directors to escape liability for a wide variety of corporate delicts that involve "good faith" or "intent" by pleading that they relied on the advice of a reputable lawyer. See Hawes \& Sherrard, Reliance on Advice of Counsel as a Defense in Corporate and Securities Cases, 62 VA. L. REv. 1 (1976). In effect, this defense inverts the gatekeeper liability strategy. Expert advice eliminates the risk of liability rather than triggering it. The bar assumes the judicial function rather than the enforcement function-to the extent that these are divisible. See Reliance on Counsel's Advice as Defense to Securities Law Violations Discussed by Longstreth, [July-Dec. 1981] SEc. REG. \& L. REP. (BNA) No. 633, at A-5 (Dec. 16, 1981) (reporting that SEC Commissioner Longstreth favors reliance-on-counsel defense despite dangers of "[a]ccommodating lawyers" and "opinion shopping"). This doctrine, then, may be viewed as a device for reducing compliance costs, rather than enforcement costs. See supra p. 880; $c f$. supra note 11 (discussing role of independent counsel in decision to indemnify). 
tion and renegotiation, perhaps in response to the imposition of greater liability. Changes in the structure and provision of outsiders' traditional services can always alter the enforcement capabilities, individual incentives, and liability risks of potential gatekeepers. The oft-noted (but still undemonstrated) transfer of legal services from outside law firms to the offices of in-house counsel is an obvious example. ${ }^{115}$ Where it extends to the responsibilities of gatekeepers, it can reflect both genuine concerns for efficiency and a strategic response to the outside law firm's gatekeeping role. ${ }^{116}$

An analysis of the scope of the director's longstanding statutory duty to monitor securities registration statements may serve to illustrate the limits of effective gatekeepers' liability. The leading judicial opinion ${ }^{\mathbf{1 1 7}}$ construes this statutory duty to extend liability to newly-elected outside directors for failing to inspect personally the disclosure contents of registration statements. ${ }^{118}$ This construction accords easily with the capabilities of inside directors, who know the firm well. Yet it appears oddly harsh when applied to those outside directors who lack special insight into the firm's finances, and who might at best be expected to watch for indications that the registration is in reliable hands and that there is nothing suspicious about the behavior or reputation of the firm's managers, auditors, or counsel. ${ }^{110}$ To the extent that the Securities Act of 1933 now imposes a

115. See Companies Expanding Legal Staffs As the Cost of Outside Work Soars, Wall St. J., Mar. 1, 1982, at 25, col. 4 (describing efficiencies of internalizing legal services). But see Pashigian, Regulation, Preventive Law, and the Duties of Attorneys, in The Changing Role of The CorpoRATE ATTORNEY 41 (W. Carney ed. 1981) (arguing that concern over shift in legal function to corporate law departments is unfounded).

116. Cf. In re Carter, [1981 Transfer Binder] FED. SEC. L. REP. (CCH) I 82,847 (SEC Admin. Proc. File No. 3-5464) (to escape objections of outside counsel, client used in-house counsel to prepare disclosure documents).

117. Escott v. Barchris Constr. Corp., 283 F. Supp. 643 (S.D.N.Y. 1968). The SEC has recently promulgated a rule delineating "circumstances" relevant to meeting the $\$ 11(\mathrm{c})$ standard of reasonable investigation. Rule 176, 17 C.F.R. $§ 230.176$ (1983). Although the rule gives explicit weight to "[r]easonable reliance on officers, employees, and others whose duties should have given them knowledge of the particular facts," $i d$., reasonable reliance is only one of eight "relevant circumstances" and clearly not a safe harbor. Neither Escott nor Rule 176 appears inconsistent with the skepticism evidenced toward outside directors in the legislative history of the 1933 Act. See infra note 120.

118. $283 \mathrm{~F}$. Supp. at $691-92$ (reliance on representations and general information unrelated to the prospectus does not satisfy outside director's burden under $\$ 11$ to exercise "reasonable care").

119. Indeed, one hapless outside director in Escott did exactly this by obtaining reports about the firm and its managers from local banks and a credit service, and evaluating the reputation of the firm's auditors. Id. at 689-92. Of course, even if Escott seems unsatisfactory on a gatekeeper rationale, it might be defended as a pure insurance incentive. See supra p. 877. The SEC's policy toward insurance for $\S 11$ liability stands in sharp contrast to its policy toward indemnification for the same risks. Compare supra note 53 (restrictions on indemnification) with Rule 461(c), 17 C.F.R. § 230.461(c) (1983) (insurance against liability for delicts not due to bad faith does not affect acceleration). This difference may stem from the fact that insurers are likely to be circumspect in their coverage and tough in their evaluation of claims when the moral hazard looms so large. Nonetheless, there is a certain inconsistency between the insurance incentive rationale-which seeks only to insure that victims will be compensated-and the goal of deterrence that is usually assumed to underlie the Act. See Globus v. Law Research Serv., 418 F.2d 1276, 1287-89 (2d Cir. 1969) (denying indemnification 
duty of personal inspection on all directors, however, the real problem may lie not in its overinclusiveness but in its constricted vision of gatekeeping possibilities. ${ }^{120}$

Viewed broadly, the outside director's duty to inspect the prospectus raises the familiar question of when liability rules should permit risk shifting in a novel way. Allowing outside directors to discharge their duty of personal inspection through reliance on reputable lawyers, accountants, and managers authorizes a new form of risk shifting. Firms can insure their outside directors by employing reputable experts, and their directors will demand such expert coverage just as they require insurance or indemnification for their garden-variety legal risks. As long as the firm's experts, in turn, bear absolute liability for breach of their own gatekeeper duties, the loss of the outside directors' personal monitoring is unlikely to matter. The corollary, of course, is that the liability of experts who are best able to monitor for wrongdoing ordinarily must be absolute unless gatekeepers' liability is imposed solely to assure compensation for the victims of firm wrongdoing. ${ }^{121}$

Thus, we return once again to the general problem of determining the proper allocation of legal risk among the firm and its participants. Gatekeepers' liability, like managerial liability, varies in its effectiveness and cost according to the extent to which, and the forms through which, these parties can shift legal risks. As with the other dimensions of gatekeepers' liability-the selection of gatekeepers and the design of their duties-risk shifting must be tailored to the realities of access to information and of influence over firm conduct for specific offenses.

because liability under $\S 11$ "was designed not so much to compensate the defrauded purchaser as to . . . deter negligence"), cert. denied, 398 U.S. 905 (1970); see also Dooley, The Effects of Civil Liability on Investment Banking and the New Issues Market, 58 VA. L. Rev. 776, 796-98 (1972) (discussing dual policies of $\S 11$ ). In addition, it is by no means clear that outside directors provide an incentive to insure in a field crowded with other insurers. A second mystery of the Escolt decision-the liability of all members of the underwriting syndicate, 283 F. Supp. at 697-is consistent with a pure compensation or insurance rationale.

120. The legislative history of the 1933 Act suggests that its drafters saw little virtue in independent directors who lacked the skill or the commitment to engage in vigorous personal monitoring of managerial policies. See Federal Securities Act: Hearings on H.R. 4314 Before the House Comm. on Interstate and Foreign Commerce, 73d Cong., 1st Sess. 16-17, 47, 123-27 (1933) (testimony of Huston Thompson) (bill intended to discourage dummy directors and misuse of directors' personal reputations to gull investors); Securities Act: Hearings on S. 875 Before the Senate Comm. on Banking and Currency, 73d Cong., 1st Sess. 80-83 (1933) (testimony of Huston Thompson) (same); id. at 205 (statement of Alexander Holtzoff, special assistant to the Attorney General) (same). This view of course overlooks the one task that even uninformed directors can perform: They can respond to the promptings of outside experts who are the natural monitors of management's actions.

121. In this context, the injury to its reputation suffered by a law or accounting firm found liable for aiding or acquiescing in a client's delict is absolute. See supra note 107. Disbarment or other administrative sanctions-such as the SEC's power to prohibit professionals from practicing before the Commission under Rule 2(e), 17 C.F.R $\$ 201.2(e)(1)(1983)$-is similarly absolute. 


\section{CONCLUSION}

The continuum from enterprise to gatekeeper liability imposes increasingly burdensome compliance costs on firms, costs that grow in tandem with the difficulty of deterring low-visibility offenses. On the one hand, the legal risks of the firm's individual participants grow more onerous as we expand the scope of absolute personal liability and the range of participants at risk. On the other hand, broadening the scope of liability and limiting opportunities for risk shifting increases the would-be offender's costs of coordinating illegal activity and "bonds" the firm's compliance more securely.

These observations, however, only begin the investigation of the relationship between penalties and organizational structure. The operation of particular systems of gatekeeper liability remains to be explored, as does the difficult issue of when gatekeeper liability is a sensible enforcement tool at all. Although gatekeeper liability is the most intrusive and most costly of the liability strategies, it may nonetheless rank below other kinds of regulatory response to chronic noncompliance on both dimensions. The next step beyond conscripting gatekeepers is, after all, to impose upon the firm specialized public monitors who are legally empowered to report wrongdoing or veto it on the spot. Thus, while gatekeeper liability is more draconian than simpler modes of dual liability, it is less intrusive than at least some forms of on-site inspection or reporting. ${ }^{122}$

Yet not only gatekeeper liability but even the apparently straightforward strategy of enterprise liability raises complex questions when it is moved from the familiar terrain of private, for-profit firms to that of public agencies and nonprofit firms. What are the organizational requisites for enterprise liability? How far do its cost advantages extend beyond the context of the conventional business firm? Recent commentary has argued the merits of enterprise liability as a tool for disciplining public agencies but has also pointed to the conceptual difficulties of identifying the "enterprise" involved. ${ }^{123}$ Large public bureaucracies may lack internal monitors with the organizational power and coherent incentives of private sector managers. The difficulty of choosing the right unit-and the right budget-to charge for public torts triggers all the familiar considerations of risk bearing, agency costs, informational access, and uncompensated harm that condition the choice of liability strategies in the private sector.

Finally, a still broader set of theoretical questions relates to the possible parallels between the design and operation of private enforcement devices

122. For example, see Christopher Stone's account of "bureaucratic constraints." Stone, supra note 5 , at $36-42$.

123. See P. Schuck, supra note 23 , at 102-06. 
and the selection of liability strategies. The progression from enterprise liability to gatekeeper liability corresponds in rough outline to a repertoire of voluntary signaling techniques that are familiar to observers of the capital markets. ${ }^{124}$ Indeed, gatekeeper liability in securities law builds on, and supplements, this array of private institutions for reducing the risk and the costs of information to outside investors. ${ }^{125}$ Similarly, contractual devices resembling gatekeeper liability occur within large firms as supplements to direct managerial controls. ${ }^{126}$ Although legal liability controls differ from these private orderings in numerous empirical and normative respects, there are important similarities as well. Private surety, bonding, and monitoring contracts generate conflicts of interest between their principals for the purpose of insuring or informing third parties. The liability of the firm's individual participants performs a similar task over the entire spectrum of corporate liability strategies: It creates, in effect, private conflicts of interest in the public interest.

124. See Gilson \& Kraakman, supra note 16 ; cf. supra note 110 (discussing division of monitoring roles among firm creditors). The privately imposed analogues of enterprise liability are costs that the firm may incur when its strategic behavior injures investors or other contracting parties. Although Ioss of reputation is the most obvious example of such a cost, firms may also contract to bear additional penalties in the event of misrepresentation or default by entering warranty, bonding, or hostage agreements. See, e.g., Gilson \& Kraakman, supra note 16; Williamson, Credible Commitments: Using Hostages to Support Exchanges, 83 AM. EcoN. REv. 519 (1983). These devices reduce the risk and information costs for third parties that are associated with the firm's representations or promises of future performance, but only when these contracts can reasonably be expected to deter the strategic behavior in question.

When such private "enterprise penalties" are not credible signals, issuers of securities may turn to other measures to increase their credibility. The analogue of managerial liability is signaling that relies directly on the incentives of individual managers. For example, outside investors may give more credit to the representations of managers who are themselves heavily invested in the firm and share the financial interests of stockholders. See Easterbrook \& Fischel, Mandatory Disclosure and the Protection of Investors, 70 VA. L. REv. (1984) (forthcoming). Similarly, the signaling function of managerial incentives may help to explain the capital structure and dividend policy of firms. See id.; Ross, The Determinants of Financial Structure: The Incentive-Signalling Approach, 8 BELL J. EcON. 23 (1977). Finally, a private analogue to gatekeeper liability may be found in risks assumed by reputational intermediaries such as investment bankers, who place established reputations on the line in vouching for the securities of unseasoned new issuers. See Gilson \& Kraakman, supra note 16.

125. See Gilson \& Krakman, supra note 16; supra p. 893.

126. A striking example is the remedy introduced by Southern Pacific Railroad to the chronic problem of employee drunkenness among train-crew members: One out of every four crew members must sign a "sniff-and-see" agreement which makes the signer responsible for all others in his crew who violate the alcohol and drug prohibition. Alchohol and Drug Use by Railuay Crewmen Poses Threat to Safety, Wall St. J., Aug. 16, 1983, at 1, col. 1. The agreement is a "desperation-type response," $i d$. at 20 , much like its legal analogue. Workers, however, apparently find it more acceptable than spot checks of blood-alcohol levels. See id. at 1. 



\section{The Yale Law Journal}

Volume 93, Number 5, April 1984

John K. Setear

Editor-in-Chief

Thomas A. Smith

Note $\mathcal{E}$ Topics Editor

Kathryn R. Abrams

Dean M. Hashimoto

Daniel C. Richman

Stephanie I. Splane Note Editors
C. Cabell Chinnis, Jr.

Managing Editor

Robert R. Harding

Pamela S. Karlan

Mercedes A. Laing

Eben Moglen

Stefan R. Underhill

Article $\mathcal{E}^{\circ}$ Book Review Editors

\section{Senior Editors}

Eric O. Corngold

Stephen E. Creager

Michael R. Hepworth

Bruce D. Judson

Paul G. Mahoney
Stephen J. Massey

Michael B. Rappaport

Jefferey M. Sellers

Thomas R. Webb

Steven J. Weingarten

Editors

Akhil R. Amar

Steven A. Baronoff

Daniel M. Bodansky

Louis M. Bograd

Reuben C. Gahn

Vikram K. D. Ghandhok

Brent M. Cohen

Lawrence P. Fletcher

Theresa Glennon
Daniel J. H. Greenwood

Michael O. Hill

Patricia A. Krieg.

Myles H. Kuwahara

Debra L. Lagapa

Patrick A. Malone

Emily McKillip

Barbara E. Pace

Michael A. Paulsen

Anne Marie Pecht
Clifford L. Rechtschaffen

Michael H. Schill

Eileen F. Serene

Liang-Houh Shieh

Susan Lynn Stewart

Kent $T$. van den Berg

Henrietta Wright

Ronald F. Wright, Jr.

Rob C. Zeitinger

Business Manager: Pamela Standish

Editorial Assistant: Claudia Shapiro

\section{Student Contributors to This Issue}

Michael O. Hill, Permanent Confuscation of Prison Contraband: The Fifth Amendment Behind Bars

Michael B. Rappaport, A Procedural Approach to the Contract Clause

Jefferey M. Sellers, Regulatory Values and the Exceptions Process 